\title{
Трансатлантические отношения во времена мультиполяр- ности: влияние на европейскую безопасность
}

Кристиан Иордан ${ }^{*}$

\author{
Свобода не бесплатна. И любые решения, \\ направленные на улучшение нашей экономики, не \\ должны ввергать нас в другой вид кризиса - \\ кризис безопасности. \\ Андерс $Ф$. Расмуссен $^{1}$
}

\section{Введение}

Экономический рост, генерируемый глобализацией мировой экономики в последние несколько десятилетий, способствовал восходу новых, набирающих международный вес, государств. Это в свою очередь привело к ожидаемым изменениям в международной системе, ставшими причиной развития теорий мультиполярного или многоцентрического мира, предполагающих наличие более сильных взаимозависимостей и множества центров могущества. Но последствия мирового финансового кризиса в настоящее время идут в разрез с этими теориями и прогнозами. На трансатлантическом уровне сочетание нескольких тенденций - сокращение бюджетов на оборону и уменьшение общественного и политического интереса к НАТО по обеим сторонам Атлантического океана и увеличение стратегического интереса США к Азиатско-Тихоокеанскому региону - может оказать негативное влияние на степень ангажированности Соединенных Штатов в делах Европы, и в результате, на европейскую безопасность.

Европа окажется в ослабленной позиции, сталкиваясь с трудностями при разрешении возможных (военных, гуманитарных и т.д.) кризисов в соседних странах, по крайней мере в краткосрочной и среднесрочной перспективе. Но пока Европа держит в руках некоторые козыри, которые позволят ей оставаться адекватным актором в будущем, основываясь на своей экономике, внутренней структуре и функционировании; у нее хорошие позиции, чтобы играть важную роль на между-

\footnotetext{
Кристиан Иордан работает в сфере кибербезопасности в качестве специалиста по международному сотрудничеству. Область его интересов и исследований включает безопасность, оборону, терроризм, гражданские свободы, права человека, разведку, защиту критической инфраструктуры и кибербезопасность, в частности на уровне Европейского Союза. У него степень магистра по международным отношениям и ученая степень доктора в области политических наук в Университете Бухареста. В 2011 году он закончил Программу передовых исследований в области безопасности, а в 2013 году - академическую программу для выпускников Центра имени Маршалла.

1 Основная речь Генерального секретаря НАТО Андерса Фог Расмуссена на парламентской ассамблее в Праге, 12 ноября 2012 года; доступно на http://www.nato.int/cps/en/SID68853CD7-CAC1A3AE/natolive/opinions_91210.htm.
} 
народном и многонациональном уровне. Чтобы достичь такого состояния в будущем, Европе придется посвятить этому большой объем мысленной энергии и ресурсов. Продолжение и углубление трансатлантических отношений - хотя и не в качестве эксклюзивного партнера - было бы естественной реакцией на вызовы двадцать первого века, и может оказаться выгодным для государств по обе стороны Атлантического океана.

\section{Новая среда безопасности двадцать первого века: от однополярности к многополярности?}

Конец Второй мировой войны обозначил начало существования относительно устойчивой международной системы с двумя великими силами - Соединенными Штатами и Советским Союзом - доминирующими в мировых экономических, политических и военных делах. После конца Холодной войны, падения коммунизма в Центральной и Восточной Европе и распада СССР в 1991 году США остались единственной мировой сверхсилой, а мир вошел в однополюсную эпоху. Впрочем, как отмечает Ян Андерсон: «Однако, спустя двадцать лет, военное перенапряжение и неразумная экономическая политика ослабили США до состояния, когда для них становится невозможно сохранять свою доминирующую роль в международных делах». ${ }^{2}$

\section{Перспективы}

К этому моменту существует несколько точек зрения на потенциальное будущее состояние мировой системы: мир может войти в новую фазу, с более сильными взаимозависимостями и множеством центров могущества, став мультиполярным или полицентрическим. Экономический рост, генерируемый глобализацией экономики, способствовал подъему развивающихся государств - БРИКС ${ }^{3}$ и других, что скорее всего приведет к изменениям в международной системе. Прогнозы о состоянии мира на 2030 основываются на тенденции диффузии могущества между странами мира. ${ }^{4} \mathrm{C}$ другой стороны, некоторые авторы говорят об эпохе аполярно-

2 Jan Joel Andersson, “The Transatlantic Relationship," Swedish Institute of International Affairs (UI) (2013).

3 Бразилия, Россия, Индия, Китай и, после 2014, Южная Африка.

4 Это включает "Global Trends 2030: Alternative Worlds," The National Intelligence Council (доступно на http://www.dni.gov/files/documents/GlobalTrends_2030.pdf) и “Citizens in an Interconnected and Polycentric World. Global Trends 2030," from the European Union's Institute for Security Studies (доступно на www.iss.europa.eu/uploads/media/ESPAS_report_ 01.pdf). Есть интересное отличие между докладами НРС и ИИБ ЕС. Методология НРС основывается на нескольких возможных сценариях, тогда как ИИБ ЕС воспринял нормативный подход, основанный на весьма оптимистической вере в «эффект декомпрессии», который дает государствам разной величины большую свободу маневра на международной арене. 
сти, об анархистическом мире (Найл Фергюсон, Збигнев Бжежинский) или даже о «новом Великом Американском Веке» (Ричард Хаасс).

Многочисленные исследования, сфокусированные на восходе Азиатско-Тихоокеанского региона в балансе мировой экономики и политического могущества, указывают на то, что к примеру, Европа и Северная Америка вместе будут превзойдены «в смысле могущества (оцениваемого по ВНП, населению, расходам на оборону, инвестициям в технологии) к 2030 году, если и не раньше. Предполагается, что будет уменьшаться относительный вес не только Европы и Соединенных Штатов, но и Японии и России». ${ }^{5}$ В результате относительного экономического успеха восходящих сил, а также просчетов, ошибок и слабостей со стороны США, в мире уже нет единственного гегемона, а есть несколько сильных государств (США, Китай, Индия, Бразилия, Россия, даже Южная Африка - и, оптимистически, ЕС), наряду с такими региональными силами среднего уровня как Турция, Мексика, Индонезия, Нигерия и т.д.

И все-таки, каковы предостережения, вытекающие из такого прогноза? Что касается проекций экономических тенденций, последние «данные являются ушатом холодной воды для экстравагантных предсказаний». ${ }^{6}$ Мы должны помнить, что эти страны зависят в разной степени от западных рынков энергии или товаров. Кроме того, заявления о том, что «доля США, Европы и Японии в мировом доходе упадет от 56 процентов сейчас до менее чем половины к 2030 году» должны быть скорректированы с учетом некоторых из ограничений, действующих на страны БРИКС. ${ }^{7}$ Эти страны сталкиваются с такими тяжелыми внутренними дисбалансами и несоответствиями, как например распределение ВНП на душу населения; этапы развития их внутренних провинций, регионов и земель (в сфере инфраструктуры, здравоохранения, жизненного стандарта и т.д.); наличие среды, способствующей потенциальному возникновению внутренних конфликтов на этнической, религиозной, территориальной, социальной и связанной с демократией почве. В некоторых случаях мы говорим не о вероятности, а о таких уже происходящих событиях, какие можно наблюдать в Китае и Бразилии. Говоря об экономическом росте, Дарон Аджемоглу и Джеймс Робинсом утверждают, «что маловероятно, чтобы Китай успел обеспечить устойчивый рост, если он не пройдет через фундаментальную политическую трансформацию, направленную на создание политических институций на широкой основе». ${ }^{8}$ Военные расходы в мировом масштабе в 2012 году впервые уменьшились с 1998 года благодаря сокращениям на

5 Andersson, "The Transatlantic Relationship."

6 Ruchir Sharma, "Broken BRICs: Why the Rest Stopped Rising," Foreign Affairs (November/ December 2012): 2-7.

7 "Global Trends 2030: Alternative Worlds."

8 Daron Acemoglu and James Robinson, Why Nations Fail. The Origins of Power, Prosperity and Poverty (London: Profile Books, 2012), 151. 
Западе, но имеет место и увеличение - в России (на 16 процентов) и в Китае (на 7.8 процентов). ${ }^{9}$

Также надо учитывать и энергетическое измерение. Китай, к примеру, все сильнее зависит от импорта ископаемых видов топлива и заинтересован в диверсификации и обеспечении безопасности своих энергетических маршрутов. Поэтому Пекин рассматривает возможность энергетического брака между Китаем и Ираном, (который) мог бы стать отправной точкой для дополнительного сотрудничества». ${ }^{10}$ Но разрешение и смягчение этих проблем и слабостей требует привлечения значительных ресурсов, планирования, но прежде всего требует времени. $^{11}$

Другой удар по этому мультиполярному тезису наносит Ручир Шарма, который заявляет, что «новый глобальный экономический порядок, вероятно, будет похож на старый больше, чем большинство наблюдателей предсказывают. Восход остальных может и будет продолжаться, но это будет подъем более медленный и неравномерный, чем ожидают многие эксперты. И очень немногие достигнут уровня доходов развитого мира». ${ }^{12}$

Другое препятствие восходу всех можно заметить на уровне координации этих восходящих государств. «Государства [формирующие] другие полюсы [могущества] более чем готовы саботировать друг друга. В большинстве случаев невозможно даже простое двустороннее партнерство». ${ }^{13}$ Для решения этой проблемы была создана Шанхайская Организация Сотрудничества, которая должна была посадить некоторые из этих государств за один стол. Но разные (политические) культуры, разные подходы к внутренней политике и внутренним ценностям, и разные позиции в отношении существенных измерений демократии, прав человека и гражданских свобод, являются большим (и возможно не подлежащим уменьшению) противоречием между этими странами.

Другой точки зрения придерживаются Найл Фергюсон и Збигнев Бжежинский, которые отвергают мультиполярную модель и предупреждают: а что, если вместо мультиполярного мира будет иметь место просто аполярная международная система с государствами, неспособными справляться с нестабильностью, погрязшую в конфликтах? Фундаментальная идея состоит в том, что в истории мировой политики кто-то всегда является гегемоном, или борется за право стать им. ${ }^{14}$ Обрисо-

9 SIPRI Yearbook 2013: Armaments, Disarmament and International Security (Stockholm: SIPRI, 2013); доступно на http://www.sipri.org/yearbook/2013.

10 "China and Iran: Best Chance for a 'Multipolar 'World," Stratfor (12 November 2004); доступно на www.stratfor.com/analysis/china-and-iran-best-chance-multipolar-world.

11 Для более детального подхода, смотри Samir Tata, "Recalibrating American Grand Strategy: Softening U.S. Policies Toward Iran in order to Contain China," Parameters 42/43 (Winter/Spring 2013): 47-58.

12 Sharma, "Broken BRICs."

13 "China and Iran: Best Chance for a 'Multipolar' World."

14 Niall Ferguson, “A World Without Power," Foreign Policy 143 (July/August 2004): 32-39; доступно на www.foreignpolicy.com/articles/2004/07/01/a_world_without_power. 
ванная аполярная перспектива весьма пессимистична, так как она может привести к Новому Мрачному Средневековью, с «исчезающими империями и религиозным фанатизмом; с эндемическим грабежом и мародерством в забытых регионах мира; с экономической стагнацией и отступлением цивилизации в несколько небольших укрепленных анклавов». ${ }^{15}$

История показывает, что «доминирование одного или другого вида ... имеет лучший шанс предотвратить развязывание войн, чем система, в которой ответственность не лежит ни на ком. ... Стабильность не есть естественный порядок вещей. ... Если какая-то сила, наперекор всем обстоятельствам, не сможет восстановить иерархию ..., мы можем ожидать большего непостоянства, большего равенства сил и, следовательно, большей анархии». ${ }^{16}$ Или как сформулировал это Джозеф Най, «война всегда была постоянным спутником и ключевым инструментом мультиполярного баланса сил». ${ }^{17}$

«Если Америка споткнется, мир вряд ли будет доминирован единственным, превосходящим других, приемником, - даже не Китаем». ${ }^{18}$ Упадок Соединенных Штатов создаст, ввиду упорного китайского национализма, период обострения напряжения в Азии. Он будет характеризоваться ухудшением безопасности более слабых государств, которые соседствуют с основными региональными силами, подвергнет риску стратегическое партнерство США с Мексикой и ухудшит менеджмент глобальных общих ресурсов. «Для США является императивом следовать новому, современному стратегическому мировоззрению в своей внешней политике», пишет Бжежинский, «или им придется готовить себя к опасному скатыванию в глобальный хаос». ${ }^{19}$ Мы, вероятно, станем свидетелями увеличения числа или степени тяжести почти конфликтных ситуаций, похожих на ситуацию на Корейском полуострове, или на дальних островах Юга (острова Спратли) и в Восточно-Китайском море (острова Сенкаку/Дяоюйдао), и кто еще знает на какие другие ситуации, некоторые из которых могут привести к полномасштабной войне.

С другой стороны, основываясь на нескольких фактах, Ричард Хаасс предвидит новый американский век: ${ }^{20}$

- Соединенные Штаты еще некоторое время останутся первым среди других государством в смысле ВНП

Там же, 34.

16 Robert D. Kaplan, “Anarchy and Hegemony," Stratfor (17 April 2013); доступно на www.stratfor.com/weekly/anarchy-and-hegemony.

17 Joseph S. Nye, "The Future of American Power," in War, Peace and Hegemony in a Globalized World, ed. Chandra Chari (New York: Routledge, 2008), 36-49.

18 Zbigniew Brzezinski, “After America," Foreign Policy (January/February 2012): 26-29; доступно на http://www.foreignpolicy.com/articles/2012/01/03/after_america.

19 Там же, 28.

20 Richard N. Haass, “The Second American Century? It's Already Here,” Washington Post (28 April 2013). 
- Соединенные Штаты располагают вооруженными силами с наиболее высокими в мире способностями

- Ни одна из основных сил не в состоянии бросить вызов Соединенным Штатам

- $\quad$ Соединенные Штаты не провоцируют прямое противостояние

- Соединенные Штаты располагают уникальной демографией и потенциалом для возобновления экономического роста, учитывая их внутренние преимущества: их географию, возрастной баланс их населения и разнообразие и таланты их общества.

«То, что стоит на пути нового Американского века, это американская политика», заявляет Хаасс. «Или мы разрешим нашу политическую дисфункцию, обдумаем заново свою внешнюю политику и восстановим основы американского могущества», или альтернативы будут такими мрачными, как предсказывали Фергюсон и Бжежински. Существующие проблемы с безопасностью и обороной Америки (перенапряжение, усталость от войн) усилились в результате кризисных ограничений по обе стороны Атлантического океана, что для восходящих государств не имело места.

Эпоха постуниполярности может, с одной стороны, иметь положительные стороны с возможностью роста для некоторых государств, демократизации развития в определенной степени и диверсификации на международной арене. С другой стороны, могут иметь место и такие отрицательные последствия, как региональное доминирование некоторых недемократических великих сил, состояния конфликта, ослабление сотрудничества и даже глобальный хаос. «Если этот нарратив американского упадка окажется даже частично правильным, тогда Соединенные Штаты будут вынуждены ребалансировать свою внешнюю политику в мире, который уже не настолько 'однозначно униполярен'». ${ }^{21}$ Г. Джон Айкенберри, однако, утверждает, что не все пока потеряно для Соединенных Штатов и их партнеров: восход Китая заставит Соединенные Штаты вспомнить, что их лидерство в западном порядке позволяет им формировать среду, в которой Китаю придется делать жизненно важные стратегические выборы, и если США хотят защитить свою ведущую роль, Вашингтону надо работать для того, чтобы укрепить нормы и институции, устанавливающие этот порядок. ${ }^{22}$

Существуют отличающиеся точки зрения на подход восходящих сил к глобальной экономике и к режиму международной безопасности, «справятся ли они со своими собственными проблемами, и более того, если они примут существую-

21 Nicholas Kitchen, ed., The United States After Unipolarity: Executive Summary, IDEAS reports SR009 (London: London School of Economics and Political Science, 2011); доступно на http://eprints.Ise.ac.uk/43473/1/The\%20United\%20States\%20after\%20unipolarity_executi ve\%20summary\%281sero\%29.pdf.

22 G. John Ikenberry, "The Rise of China and the Future of the West," Foreign Affairs 87:1 (January/February 2008); доступно на www.foreignaffairs.com/articles/63042/g-johnikenberry/the-rise-of-china-and-the-future-of-the-west. 
щий мировой порядок, или они начнут его изменять». Майлес Кахлер утверждает, что восходящие государства «являются умеренными реформаторами, которые стремятся к большему влиянию в существующих форумах, а также пытаются защитить свою автономность в проведении политики». ${ }^{23}$ Однако, как отмечает Севасти-Елени Везирджианиду, «Люди, определяющие политику США, должны понимать, в каком направлении их текущие решения сдвигают мировой порядок; если они не желают такого порядка, они должны пересмотреть свою стратегию в отношении как восходящих, так и небольших сил, и должны продемонстрировать больше лидерства в реформировании официальных институций». ${ }^{24}$

Что касается ЕС, это один из наиболее хорошо позиционированных акторов для многостороннего, мультиполярного мира, даже если учитывать только его культуру ведения переговоров и дипломатии и широко признанной в мире ауры виртуоза применения мягкой силы. Тема мультиполярности трактуется Альваро де Васконселос с такой точки зрения - расширение многосторонности мультиполярности: «Европа должна быть в состоянии определить вместе с другими мировыми и региональными силами нормы и правила, которые необходимы для стимулирования согласованных усилий избегать будущих столкновений соперничающих приверженцев унилатерализма. ... Сочетание активного возвращения Америки к мультилатерализму и желание получить мировое признание других основных игроков открывает окно возможностей для определения общего распорядка дня для движения в сторону эффективного мультилатерализма и реформирования таких институций глобального управления», как $\mathrm{OOH}$, рамки, которая пользуется авторитетом среди восходящих государств.

Восход нескольких новых великих сил есть факт очевидный; будут ли они в состоянии соперничать с США на глобальном уровне, вопрос спорный. Из этого сдвига в балансе сил проистекают существенные вопросы, касающиеся возможных последствий, точнее относительно потенциала для увеличения внутригосударственных и межгосударственных конфликтов, распространения региональной нестабильности и потенциала для создания нестабильности на глобальном уровне. Так же, будут ли в состоянии экономически более сильные Китай или Индия утвердить себя на международной сцене в ближайшем будущем? Сколько времени у них уйдет на то, чтобы трансформировать экономическое могущество в военное, а затем проецировать его на международной арене? При наличии кризиса, который стучится в дверь, странам БРИКС, возможно, придется отложить момент, чтобы бросить вызов Западу. В этот момент трансатлантическое партнерство может показать некоторые из своих сильных сторон, включающих наличие общих ценностей, общей культуры, общего уровня развития и т.д., и многочисленные форумы, которые были созданы для осуществления и поощрения координации.

23 Miles Kahler, "Rising Powers and Global Governance: Negotiating Change in a Resilient Status Quo," International Affairs 89:3 (May 2013): 711-29.

24 Sevasti-Eleni Vezirgiannidou, "The United States and Rising Powers in a Post-hegemonic Global Order," International Affairs 89:3 (May 2013): 635-51. 
Для трансатлантических партнеров возможности налицо, но для четкого определения приоритетов и подходов к глобальным делам необходимы существенные изменения как в США, так и в Европе.

\section{Взгляды и подходы США: новый баланс}

Такие глобальные изменения, как восход других государств, подтолкнули США к инициированию процесса установления приоритетов и проведения углубленного анализа их глобального влияния, весьма непростой задачи, имея в виду «существенные бюджетные и экономические ограничения, накладываемые задолженностью федерального правительства, которая набухла до 16 триллионов долларов США или около 100 процентов от ВНП, и продолжающимся замедлением экономического развития...». ${ }^{25}$ После тринадцати лет участия в конфликтах за океаном США устали от войны, сталкиваются с серьезными бюджетными проблемами, оказываются лицом к лицу с серьезнейшими вопросами, касающимися вызовов перед их потенциально ослабевающем лидерстве в мире. Процесс обновления общей стратегии Соединенных Штатов был отложен из-за нескольких факторов, как отметила Везирджианиду: их «давней позиции лидера «свободного мира» во времена Холодной войны, а затем бесспорного гегемона в геополитической сфере в первом десятилетии после конца Холодной войны; также потому, что упадок будет происходить в течение некоторого времени, и поэтому решение об общей стратегии соответственно можно отложить». ${ }^{26}$

\section{Ненадежные времена}

Относительно роли Соединенных Штатов в мире изобилуют неопределенности, а потому существуют разные взгляды на лучший подход к их будущей стратегии. Некоторые авторы отдают предпочтение сокращениям, другие - дальнейшей проекции военного присутствия и участия. Таким образом, «настоящий вопрос», пишет Эрик Гобсбаум, «в том, возможен ли исторически беспрецедентный проект глобального доминирования одного государства, и достаточно ли доказанное подавляющее военное превосходство США для его достижения и ... поддерживания». 27

По мнению сторонников сокращений, например согласно Барри Посену, США слишком увеличили свои расходы на безопасность и оборону, основываясь на «недисциплинированной, дорогостоящей и кровавой стратегии, [которая] нанесла невиданный вред национальной безопасности США. ... Наступило время отказаться от стратегии гегемонии США и заменить ее стратегией сдерживания. Это

25 Samir Tata, "Recalibrating American Grand Strategy."

26 Sevasti-Eleni Vezirgiannidou, "The United States and Rising Powers in a Post-hegemonic Global Order."

27 Eric Hobsbawm, "War, Peace and Hegemony at the Beginning of the Twenty-First Century," in War, Peace and Hegemony in a Globalized World, ed. Chandra Chari (New York: Routledge, 2008), 15-24. 
означает отказаться от глобальной реформы и придерживаться защиты узких интересов национальной безопасности, трансформируя вооруженные силы в меньшую военную силу, убирая большое количество американских войск из вынесенных вперед баз, создавая стимулы для союзников начать обеспечивать свою собственную безопасность». ${ }^{28}$

Что касается отношений с союзниками Соединенных Штатов, которые сократили свои военные расходы до беспрецедентного уровня (в среднем среди европейских членов НАТО это 1.6 процентов ВНП), его основной пункт состоит в том, что США «должны пересмотреть свои союзы так, чтобы другие страны разделяли фактическую ответственность за свою собственную оборону. ... Вооруженные силы США можно было бы существенно сократить, чтобы сэкономить деньги, а так же чтобы показать союзникам, что им пора делать больше для самих себя». ${ }^{29}$ Эндрю Басевич пропагандирует похожий подход: надо позволить европейцам повзрослеть с точки зрения безопасности и обороны. ${ }^{30}$ Таким образом, США могли бы осуществлять более выборочное присутствие на международной арене, но могли бы продолжить «играть яркую глобальную роль, тем временем обращая внимание на способы, которыми США преследуют свои цели. Ограничения не должны подрывать то, что Соединенные Штаты делают». ${ }^{31}$ Откладывание будущей масштабной стратегии составляет смертельную опасность: «Наше состояние будет непозволительным, несоответствующим новым изменениям, и во все большей степени доминированным схемами осуществления расходов, которые не поддерживают напрямую наиболее подходящие формы национальной мощи». ${ }^{32}$

Действительно, теория «оффшорного балансирования» Кристофера Лейна утверждает, что США не обязаны интервенировать; их позиция в 1939-40 была не изоляционистской, а «интеллигентным примером оффшорного балансирования. ... Соединенные Штаты в достаточной степени защищены от внешних угроз ... так, что они могли бы предпочесть сдерживание перед вмешательством. ... И им следует сделать это». ${ }^{33}$ Ревизированная в 2002 году, эта концепция рассматривается как принятие других игроков на мировой сцене, как констатация факта, что

28 Barry R. Posen, "Pull Back: The Case for a Less Activist Foreign Policy," Foreign Affairs 92:1 (January/February 2013).

29 Там же.

30 Andrew Bacevich, "Let Europe Be Europe: Why the United States Must Withdraw from NATO," Foreign Policy (March/April 2010); available at www.foreignpolicy.com/articles/ 2010/02/22/let_europe_be_europe.

31 Смотри очень глубокую, подробную, политически ориентированную работу Michael J. Mazarr and the NDU Strategy Study Group, "Discriminate Power: A Strategy for a Sustainable National Security Posture," The Philadelphia Papers 2 (Mау 2013); доступно на www.fpri.org/articles/2013/05/discriminate-power-strategy-sustainable-national-security-

32 posture.

32 Там же.

33 Christopher Layne, "From Preponderance to Offshore Balancing: America's Future Grand Strategy," International Security 22:1 (Summer 1997), 86-124. 
«Соединенные Штаты не могут препятствовать восходу новых великих сил как внутри (ЕС, Германия и Япония), так и вне сферы их влияния (Китай, возрождающаяся Россия). Оффшорное балансирование так же облегчило бы бремя США управления безопасностью таких турбулентных регионов, как Персидский залив/ Ближний Восток и Юго-Восточная Европа». ${ }^{34}$

Однако, теории сокращения не учитывают долгосрочную поддержку Америкой глобализации и выгод от глобализации. США все еще являются самой могучей военно-морской силой в мире, что необходимо для защиты торговли и их глобальных интересов. С другой стороны, в большей или в меньшей степени, любое значительное государство должно быть заинтересовано в безопасности и надежности мировых морских путей - смотри, к примеру, антипиратские операции у берегов Африканского рога. Китай, Бразилия, Австралия, не говоря уже об ЕС (и так далее) могут инвестировать в сотрудничество с США в этой сфере. Международное присутствие в Индийском океане вокруг Африканского рога является хорошим примером в этом смысле.

Другая слабость упомянутой выше позиции состоит в том, что она не берет в расчет сложные экономические, социальные и политические отношения между Европой и США. В конце концов, не в национальных интересах Америки разрывать или ослаблять свои трансатлантические связи, ${ }^{35}$ терять друзей и попадать в изоляционистскую ловушку некоторого рода. Европейцы боятся, что Соединенные Штаты могут повернуться спиной к остальному миру, и сланцевая революция рассматривается некоторыми авторами как еще один стимул для отступления, так как она делает США, как сказал президент Обама в марте, «менее зависимыми от того, что происходит на Ближнем Востоке». ${ }^{36}$ Но степень, в которой США зависят от нефти Ближнего Востока, является только одной из причин заинтересованности США в этом регионе.

\section{Смещуение цуентра тяжести - в сторону от чего?}

Это есть контекст, который вызывает недоуменное поднятие бровей от ситуации в Азиатско-Тихоокеанском регионе, но прежде всего в Европе, с объявленного администрацией Обамы в 2011 году смещение «центра тяжести» или стратегического поворота к Азии. Хотя секретарь государственного департамента США Хиллари Клинтон описала сдвиг в сторону Азии как сдвиг вместе с Европой, очевидно европейцы задавали себе весьма простой вопрос с не настолько простым ответом «В сторону от чего?». ${ }^{37}$ Некоторое уточнение терминологии, но не поли-

34 Christopher Layne, "Offshore Balancing Revisited," The Washington Quarterly 25:2 (Spring 2002): 233-248, цитата на с. 245.

35 К примеру, многомиллиардное трансатлантическое соглашение о свободной торговле «Трансатлантическое Торговое и Инвестиционное Партнерство» (ТТИП), в настоящее время в процессе переговоров.

36 Benjamin Alter and Edward Fishman, "The Dark Side of Energy Independence," The New York Times (28 April 2013).

37 Hillary Clinton, “America's Pacific Century,” Foreign Policy 189 (November 2011): 56-63. 
тики, было опубликовано позже Советом Национальной Безопасности, в котором ставшее печально известном «смещение центра тяжести» было заменено на «ребалансирование», внушая идею, что речь идет о продолжающемся процессе тонкой настройки: ${ }^{38}$ «Хотя нет никаких сомнений, что сейчас Азиатско-Тихоокеанский регион важнее, чем когда-либо, эта фраза сигнализировала, что другие регионы, прежде всего Европа и Африка, стали менее значимыми». ${ }^{39}$

Подобным образом министр обороны США Чак Хейгел придерживается мнения, что перебалансирование способностей и ресурсов к Азиатско-Тихоокеанскому региону не надо толковать неправильно. «У США есть союзники, интересы и ответственности по всему миру. Поворот к Азии не является отступлением из других регионов мира. Однако, мир проходит через период исторических трансформаций, и Азия является эпицентром этих изменений». ${ }^{40}$ Военные способности и военный потенциал США переориентируются для того, чтобы лучше подготовиться к будущим вызовам глобальной безопасности.

С практической точки зрения, усиление военного фокуса США в Азиатско-Тихоокеанском регионе было проиллюстрировано Руководителем военно-морскими операциями, адмиралом Джонатаном У. Гринертом, и Командующим корпусом морской пехоты, генералом Джемсом Ф. Амосом, первоначальной дислокацией 250 морских пехотинцев США в самый северный город Австралии - Дарвин, число которых к 2014 году должно быть увеличено до уровня экспедиционного отряда морской пехоты (около 1000), перепозиционированием военно-морских сил США в Тихоокеанский регион (например в Сингапур) и китайским интересом к участию в следующих ежегодных учениях «Rim of the Pacific» RIMPAC $14 .{ }^{41}$

Есть несколько важных вопросов, которые подразумевает ребалансирование. Во-первых, каковы цели Соединенных Штатов в отношении Китая: сдерживание (по мнению Пекина) или хеджирование (согласно Вашингтону), означающее одновременное балансирование и сотрудничество. По мнению Елени Везирджианиду, до сих пор США были весьма сдержаны в привлечении Китая в конструктивном плане, в смысле включения в международную систему. ${ }^{42}$ Во-вторых, с

38 Смотри "Looking Forward: U.S. National Security Beyond the Wars," conference organized by the Center for a New American Security, 12 June 2013; подробности на http://pomed.org/ wordpress/ wp-content/uploads/POMED-Notes-CNAS-conference.pdf.

39 James Joyner, “Jones: 'Pivot to Asia' Regrettable Word Choice," New Atlanticist (3 January 2013); доступно на http://www.atlanticcouncil.org/blogs/new-atlanticist/jones-pivot-to-asiaregretable-word-choice.

40 Chuck Hagel, "The U.S. Approach to Regional Security," speech at the Shangri-La Dialogue, International Institute for Strategic Studies, 1 June 2013.

41 Смотри "Military Strategy Forum on The Future of Maritime Forces," The Center for Strategic and International Studies, a discussion with Admiral Jonathan W. Greenert, Chief of Naval Operations, and General James F. Amos, Commandant of the Marine Corps, CSIS, Washington DC, 11 July 2013.

42 Sevasti-Eleni Vezirgiannidou, "The United States and Rising Powers in a Post-hegemonic Global Order." 
европейской стороны, реакция была очень осторожной, показывая озабоченность о трансатлантических отношениях, что привело к дипломатическому туру государственного секретаря США Джона Керри по нескольким европейским столицам весной 2013 года. Итак, как США могли бы привлечь европейцев к участию в эту деятельность? Она могла бы дать возможность для расширения трансатлантического сотрудничества, если бы ЕС поддержал усилия США по крайней мере в двух сильных для ЕС направлениях: в экономике и политике. ${ }^{43}$ Европейцы, по крайней мере некоторые из них, так же должны напомнить США, что перенос центра тяжести мог бы предоставить возможность более упорному конкуренту расширить свое влияние. Наряду с развитием вооруженных сил Китая, европейская экономика является ключевой для интересов США областью. Таким образом Китай и Европа представляют собой «два региона мира, которые наиболее важны для долгосрочных экономических и политических американских интересов», и это так же требует «твердой готовности применять американскую жесткую силу». ${ }^{4}$

\section{Секвестр и его последствия}

Установление целей и выбор стратегий включает оценку наличных ресурсов, которые имеются уже не в таком количестве, как несколько лет назад, до того как западные капиталистические демократии, как очевидно, попали в ловушку глобального экономического кризиса. Последствия кризиса простираются от общественного благосостояния и зарплат до, как тоже очевидно, сферы безопасности и обороны, которая уже была потрепана - по крайней мере, в Европе - уже имевшей место тенденцией уменьшения бюджетов. В 2013 пришла очередь США, с применением так называемого «бюджетного потолка» с 1 марта - автоматического механизма, вынуждающего публичный сектор реализовать сокращения бюджетов для того, чтобы контролировать спирально увеличивающийся дефицит. Что касается сектора обороны, числа изумительны, по крайней мере с европейской точки зрения: уменьшение бюджета на 2013 финансовый год на 52 миллиарда долларов США. Ева Гросс пишет:

Если секвестирование продолжится (что будет иметь место, пока демократы и республиканцы не договорятся о бюджете, который включает требуемые сокращения), бюджет на оборону за следующие десять лет будет урезан на не менее чем 500 миллиардов долларов в виде сокращений планированного увеличения. ... Уменьшение на 489 миллиардов долларов уже расписано как часть ЗКБ [Закона о контроле за бюджетом] от августа 2011 года, в результате компромисса, сделанного для поднятия потолка государственного долга США. Проектируемые секвестриальные сокращения, 500 миллиардов в течение следующих десяти лет, будут сделаны допол-

43 Смотри Henriette Rytz, "The Pivot to Asia - Overcoming a Communication Problem," German Institute for International and Security Affairs (SWP) (11 February 2013); доступно на http://www.swp-berlin.org/en/publications/point-of-view/point-of-view-the-pivot-to-asiaovercoming-a-communication-problem.html.

Robert D. Kaplan, “The Virtues of Hard Power,” Stratfor (22 May 2013). 
нительно к этим сокращениям». ${ }^{45}$ Но это не все: «начиная с 2014 финансового года, Министерству обороны, вероятно, придется сокращать свои бюджеты как минимум на 60 миллиардов ежегодно до конца этого десятилетия». ${ }^{46}$

Дело усложняется еще больше тем, что расходы на военный персонал (зарплаты, медицинские страховки и другие льготы) выросли почти в два раза с 2001 финансового года, и теперь поглощают одну треть основного бюджета Пентагона - около 180 миллиардов долларов в год. ${ }^{47}$ Кроме того, в июле 2013 пришло время отпусков тысяч гражданских служащих министерства обороны.

В этом трудном и необычном для истэблишмента безопасности и обороны США контексте Министр обороны США Чак Хейгел приказал высшим сотрудникам Пентагона вновь рассмотреть военную стратегию США, принятую в прошлом году, с тем, чтобы посмотреть, как придется приспосабливать приоритеты к планируемым сокращениям бюджета. ${ }^{48} \mathrm{~B}$ свете этого, заявление Пентагона об уменьшении числа военных кораблей, дислоцируемых по всему свету, рассматривается как тревожный сигнал. Недавняя отмена развертывания авианосца Трумэн и сопровождающей его ударной группы был прямым следствием секвестра. Впервые в течение десятилетия военно-морской флот США будет располагать только одной авианосной ударной группой, патрулирующей в Персидском заливе. ${ }^{49}$

Дов Закхайм, бывший помощник министра обороны, отвечающий за финансы, отмечает: ${ }^{50}$ «Секвестр является весьма глупым способом для разрешения бюджетных проблем Америки. На деле, он может только их углубить. ... Если секвестр будет продолжен, оборонный бюджет придется сокращать до 2021 года в целом

45 Eva Gross, "The American Sequester and Us," European Union Institute for Security Studies, Brief No. 19 (22 April 2013); доступно на www.iss.europa.eu/publications/detail/article/theamerican-sequester-and-us.

46 Dov S. Zakheim, "The Strategic Implications of a Freefalling U.S. Defense Budget," The American Interest (July-August 2013): 43-51; доступно на www.the-american-interest.com/ article.cfm?piece $=1431$.

47 U.S. Department of Defense, Overview - United States Department of Defense Fiscal Year 2013 Budget Request (Washington, D.C.: U.S. Department of Defense, 2012), 43; доступно на http://comptroller.defense.gov/defbudget/fy2013/FY2013_Budget_Request_Overview_ Book.pdf. Смотри еще Lawrence J. Korb, Alex Rothman, and Max Hoffman, "Reforming Military Compensation: Addressing Runaway Personnel Costs Is a National Imperative," Center for American Progress (7 Mау 2012); доступно на www.americanprogress.org/issues/ security/report/2012/05/07/11573/reforming-military-compensation.

48 Смотри David Alexander, "Defense Chief Orders Strategy Review in Response to Budget Cuts," Reuters (18 March 2013); доступно на http://www.reuters.com/assets/print?aid= USBRE92H0S620130318.

49 Jan Joel Andersson, "The Transatlantic Relationship," Swedish Institute of International Affairs (UI) (2013). Смотри еще David Alexander, "Update 1 - Pentagon Delays Carrier's Mideast Deployment over Budget Woes," Reuters (6 February 2013); доступно на www.reuters.com/ article/2013/02/07/usa-budget-pentagon-idUSL1N0B6ME520130207.

50 Главный помощник и советник Министра обороны и Заместителя министра обороны по всем бюджетным и налоговым проблемам. 
примерно на 1.2 триллионов доллара. Если администрация не предпримет существенных шагов для уменьшения головокружительных расходов МO, ей придется уменьшать уровень сил, их расположение, развертывание и другие операции. Как это обрисовал министр обороны в то время Леон Панетта ... 14 ноября 2011, секвестр приведет к наименьшему с 1915 года Военно-морскому флоту, наименьшим с 1940 года Сухопутным войскам, и наименьшим Военно-воздушным силам вообще когда-либо». ${ }^{51}$

Оборонный истэблишмент США должен принять участие в стратегическом обзоре последствий бюджетных проблем, учитывая, что в результате этих проблем были отменены некоторые исследовательские программы и программы по разработке, уменьшены поставки, расходы на военную подготовку, учения, летные часы и т.д., и таким образом снижена боевая готовность вооруженных сил, и что более важно - их долгосрочная боеспособность. Во времена переоценки приоритетов и оценки наличных ресурсов существует искушение прибегнуть к ограничительным подходам - как это случалось раньше, хирургическая тактика находит сторонников во времена бюджетных ограничений. Однако «почти всегда необходимо сбалансированное применение военной силы для достижения решающих результатов в войне. ... Ответственные стратеги должны думать о расходах и рисках как о неизбежных элементах игры. Когда два стелт бомбардировщика В2 стоят больше, чем весь парк боевых танков действующих Сухопутных сил, что-то не в порядке». ${ }^{52}$ В равной степени надо учитывать и человеческое измерение, от снижения мотивации до увеличения контрразведывательной податливости. Случай Сноудена является наиболее очевидным примером потенциального урона, который могут нанести действия недовольных сотрудников.

\section{Секвестр и его возможности}

С другой стороны, к этой теме так же можно применить историю о наполовину полном стакане. Некоторые наблюдатели чувствуют, что ограничения, накладываемые секвестром, «могут оказаться полезными, если они предотвратят новый всплеск избыточного дорогостоящего американского интервенционизма». ${ }^{53}$ США могли бы найти силы изменить свой нынешний способ ведения дел и тщательно рассмотреть несколько возможностей, таких как: гибкие силы, модульные способности и вынесенное вперед присутствие ${ }^{54}$ всегда увеличивающаяся роль разведки и сил для специальных операций, которые предназначены действовать ниже порога войны; другой, более интегрированный подход к исследованиям и техноло-

51 Zakheim, "The Strategic Implications of a Freefalling U.S. Defense Budget."

52 Richard D. Hooker, “The Strange Voyage': A Short Précis on Strategy,” Parameters 42 (Winter-Spring 2013): 59-68.

53 Zakheim, "The Strategic Implications of a Freefalling U.S. Defense Budget."

54 "Military Strategy Forum on The Future of Maritime Forces," The Center for Strategic and International Studies, a discussion with Admiral Jonathan W. Greenert, Chief of Naval Operations, and General James F. Amos, Commandant of the Marine Corps, CSIS, Washington D.C., 11 July 2013. 
гиям, совместная для видов вооруженных сил разработка, приобретение и поставка; ${ }^{55}$ расширенное использование беспилотных систем во всех видах вооруженных сил и родах войск, в том числе БЛА (беспилотных летательных аппаратов) и УБЛА (ударных беспилотных летательных аппаратов) для сбора разведывательной информации, наблюдения и даже боевых миссий. 10 июля 2013 Военноморской флот провел успешные испытания прототипа УБЛА фирмы Northrop Grumman c обозначением X-47B, который самостоятельно, без участия человека, сел на авианосец два раза с трех попыток. ${ }^{56}$ Развитие беспилотных технологий указывает на изменение роли авианосцев, ${ }^{57}$ учитывая необходимость адаптироваться к технологиям и способностям для запрета доступа, ${ }^{58}$ которые разрабатывают другие государства, не говоря уже о расширяющейся сфере киберспособностей (как оборонительных, так и наступательных). ${ }^{59}$

В этом контексте Соединенным Штатам придется работать со своими союзниками или они просто будут не в состоянии обеспечивать свои глобальные интересы. Они определенно являются мировой сверхсилой, но будут ли они ею в будущем? Европейцы могут помочь; они все еще пользуются экономическим весом, но им необходимо продемонстрировать больше стратегической ориентации и больше желания делить бремя безопасности.

55 Claudette Roulo, "Hagel Meets with Troops on Fort Bragg, Discussed Budget," U.S. Department of Defense Website (15 July 2013); доступно на http:/www.defense.gov/news/ newsarticle.aspx?id=120456.

56 Параллельная бордовая компьютерная система решила, что УБЛА при третьей попытке должен сесть на твердую землю. Смотри Sydney J. Freedberg, Jr. and Colin Clark, "Navy, Northrop Score Historic First With (Mostly) Successful X-47B Drone Carrier Landings," Breaking Defense (10 July 2013); доступно на http://breakingdefense.com/2013/07/10/navynorthrop-score-historic-first-with-successful-x-47b-drone-carrier-landing/.

57 «Авианосный корабль находится под угрозой стать как те боевые корабли, которым первоначально он был предназначен оказывать поддержку: большим, дорогостоящим и уязвимым - изумительно несоответствующим конфликтам современности». Capt. Henry J. Hendrix, USN, "At What Cost a Carrier?", Center for a New American Security (March 2013); доступно на www.cnas.org/files/documents/publications/CNAS\%20Carrier_Hendrix_ FINAL.pdf.

58 Смотри документ, подготовленный для армии Соединенных Штатов Джоном Гордоном IV и Джоном Мацамура, The Army's Role in Overcoming Anti-Access and Area Denial Challenges (Santa Monica, CA: RAND Corporation, 2013); доступно на www.rand.org/ content/dam/rand/pubs/research_reports/RR200/RR229/RAND_RR229.pdf.

59 Такие как китайская ракета Донг Фенг 21D, противокорабельная баллистическая ракета (ПКБР) дальностью приблизительно в 2000 км. Смотри J. Michael Cole, “The DF-21D or 'Carrier Killer': An Instrument of Deception?”, The Diplomat (22 April 2013); доступно на http://thediplomat.com/flashpoints-blog/2013/04/22/the-df-21d-or-carrier-killer-aninstrument-of-deception. 


\section{Восприятие и развитие событий в ЕС}

Сильное влияние широкомасштабных конфликтов в истории Европы определило европейское чувство осторожности в отношении военных расходов и военной культуры. Похоже, что Европа все еще боится своего прошлого; она отвергает войну до степени, которую Президент совета по внешним отношениям Ричард Хаасс описал как «резко выраженную антивоенную культуру». ${ }^{60}$ Эта позиция была усугублена ощущением отсутствия каких бы то ни было существенных угроз в период после Холодной войны (и небольшим масштабом большинства конфликтов в то время), что привело к постмодерному (по мнению некоторых ${ }^{61}$ ) и идеалистическому (по мнению других ${ }^{62}$ ) подходу к мировым делам.

К его чести, Европейский Союз показал, что он успешно снизил вероятность войны между его членами до уровня «который невозможно себе представить». Но каков статус Европы на международной сцене? Почему оборона имеет значение в период после Холодной войны, что касается Европы? Обречена ли Европа оставаться «нормативной силой»? Есть ли в Европе восприятие угрозы?

\section{Какой вид силье?}

Европейский Союз не является государством, но не является и классической международной организацией. Скорее, это странный объект в международном праве, идентифицируемый как постмодерный объект на международной сцене. ${ }^{63}$ Благодаря своему непропорциональному влиянию на международную экономику, особенно если сравнивать с его военным потенциалом, ЕС остается все так же трудно поддающимся классификации, и его роль в качестве международного актора порождает многочисленные споры. ${ }^{64}$ Критики считают, что его автономность при принятии решений недостаточна для того, чтобы присвоить ему статус международного актора.

По мнению Джона Мершеймера, ЕС не является великой силой, так как он не удовлетворяет необходимым кумулятивным критериям: у него есть ресурсы и население, но нет военной силы. ${ }^{65}$ Это выражается не только в численности и

${ }^{60}$ Richard N. Haass, "The Second American Century? It's Already Here,” Washington Post (28 April 2013).

61 James A. Caporaso, "The European Union and Forms of State: Westphalian, Regulatory or Post-modern?" Journal of Common Market Studies 34:1 (March 1996): 29-52.

62 Robert Kagan, Of Paradise and Power: America and Europe in the New World Order (New York: Alfred E. Knopf Editions, 2003).

63 Caporaso, "The European Union and Forms of State."

${ }^{64}$ Смотри Roy H. Ginsberg, "Conceptualizing the European Union as an International Actor: Narrowing the Theoretical Capability-Expectations Gap," Journal of Common Market Studies 37:3 (September 1999): 429-454. Смотри еще Franck Petiteville, "L’Union Européenne comme acteur international 'global.' Un agenda de recherche," Revue Internationale et Stratégique 47:3 (2002): 145-57; Franck Petiteville, La politique internationale de l'Union Européenne (Paris: Presses Sciences Po, 2006), 193-231.

65 John J. Mearsheimer, The Tragedy of Great Power Politics (New York: W.W. Norton, 2001). 
качестве подготовки его войск, но и в отсутствии передовой военной индустрии. Точнее, в Европе есть оружейная промышленность, но она не европейская - она фрагментирована, и каждое государство поддерживает своего национального чемпиона. ${ }^{66}$

Другие авторы придерживаются подхода, основанного на идентификации четырех критериев, которые должен выполнить ЕС для того, чтобы претендовать на статус международного актора: ${ }^{67}$

1. Признание такого статуса другими акторами на международной арене

2. Правовое основание действовать в международном плане

3. Определенный уровень автономии принятия решений ЕС (Европейской комиссией) по отношению к странам-членам ${ }^{68}$

4. Минимальный уровень когерентности в осуществлении своих внешних отношений.

Лиссабонский Договор (2007) учитывает эти пункты, внося некоторые инновации, какими бы скромными они не были:

- Постоянная должность Президента Европейского Совета (бельгиец Херман Ван Ромпой)

- Новый Верховный представитель Союза по иностранным делам и политике безопасности

- Вице-президент Комиссии (Леди Кэтрин Эштон)

- Создание Европейской службы внешнеполитической деятельности для содействия Верховному представителю

- Развитие единой правосубъектности для Союза

- Возможность усиленного сотрудничества малых групп стран-членов по вопросам Общей политики безопасности и обороны.

Однако, все еще существуют препятствия для полного стратегического существования Союза, и Николь Гнесотто подтверждает, что «одно из самих больших ... можно найти в самой Европе, в тех старых европейских нациях, которые придумали и затем возвысили национальный суверенитет в качестве фундаментального принципа политического порядка, а сейчас колеблются, применять ли его, или у них нет такого желания, или думают не пойти ли дальше. ... Политическая Европа, а военная тем более, остается суммой государств, которые являются суве-

66 Cristian Iordan, "Le système européen d'acquisition d'armements. Facteur de soutien de la PESD," Romanian Journal of European Affairs 10:4 (December 2010): 87.

67 Joseph Jupille and James A. Caporaso, "States, Agency and Rules: The European Union in Global Environment Politics," in The European Union in the World Community, ed. Carolyn Rhodes (Boulder, CO: Lynne Rienner, 1998), 213-229.

68 Это само по себе является спорной темой, более важной в сфере торговли и сотрудничества, чем в сфере безопасности и дипломатии. 
ренными и желают остаться такими». ${ }^{69}$ Надо иметь в виду и внутренне присущую институциональную сложность ЕС - его зависимость от двадцати восьми странчленов, а так же и конфликт между наднациональными и межгосударственными взглядами - что работает против когерентного описания ЕС как «коллективного» актора». ${ }^{70} \mathrm{EC}$ упражняет международное влияние, участвуя в международной торговле, оказании гуманитарной помощи или в разрешении конфликтов, что позволяет принимать его за международного актора, независимо от его незаконченности в этом плане.

А если это так, то встает вопрос: какого вида международным актором является ЕC? Олицетворяет ли он мягкую, гражданскую или нормативную силу? На практике, эти концепции или взгляды взаимосвязаны и основываются на непринудительном влиянии ЕС на международные отношения, поддерживаемым «экспортом или диффузией норм». ${ }^{71}$ Европа не может отойти от идеи мягкой силы, которая предполагает использование коллективных средств для убеждения третьих сторон в правомерности ваших аргументов, оказывая привлекающее влияние на них, развертывая ресурсы на трех уровнях: культура, политические ценности и внешняя политика. ${ }^{72}$ Концепция гражданской силье, дефинированная Гансом Маулом, предполагает принятие необходимости в сотрудничестве с другими для достижения международных целей; сосредоточение на невоенных, на первом месте экономических средств для обеспечения национальных целей, оставляя военную мощь в качестве остаточного инструмента в основном для защиты других средств международного взаимодействия; и желание развивать наднациональные структуры для решения критических вопросов, требующих международного менеджмента. Что касается концепции нормативной силь, она предполагает, что ЕС построен на правовых нормах, и что он может действовать в мировой политике нормативным способом. В принципе это хорошо - проблема в том, можно ли ожидать то же самое от других акторов на международной сцене. Как отмечает Ян Маннерс, «Не являясь просто противоречием в терминологии, способность определить, что в мировой политике надо считать «нормальным», в итоге становится самой большой силой». ${ }^{73}$

69 Nicole Gnesotto, La politique de sécurité et de défense de l'UE. Les cinq premières années (1999 - 2004) (Paris: EU Institute for Security Studies, 2004), 21.

70 Jupille and Caporaso, "States, Agency and Rules," 214.

71 Franck Petiteville, La politique internationale de l'Union Européenne (Paris: Presses Sciences Po, 2006), 229.

72 Joseph Nye, Soft Power: The Means to Success in World Politics (New York: PublicAffairs, 2004), 6 .

73 Ian Manners, "Normative Power Europe: A Contradiction in Terms?", JCMS 40:2 (2002): 252-53. 


\section{Ограничения}

Теория о Европе как о нормативной силе предлагает тему для высоко интеллектуальной дискуссии, но к сожалению, плана «Б» нет. А что, если вы не сможете убедить или договориться о выходе из проблематической ситуации?

Не желая посвятить серьезное обдумывание и ресурсы своей безопасности и обороны на решение этой задачи, Европа, похоже, думает, что просто может остаться в стороне от всего этого, сосредотачивая свои усилия на актуальных проблемах затянувшегося экономического кризиса, занимая позицию в некотором роде бесплатного проезда. Таким образом, в итоге европейские государства платят всего 20 процентов от общего счета НАТО, и хотя члены ЕС покрывают четверть от глобальных военных расходов, только малая толика идет на ОПБО, в которой не хватает способностей и экспертов, но прежде всего стратегической когерентности. Оборонный бюджет ЕС за последние десять лет уменьшился с 251 миллиарда до 194 миллиардов евро. ${ }^{74}$ ОПБО движется не соображениями об эффективности; она имеет характер реакции, «определяемой событиями». Европейцам понадобилось немало времени, чтобы вмешаться в Косово, на Африканском роге, в Ливии и Мали.

ЕС все еще пытается найти стратегический путь (пути) и инициировал совместную способность для стратегического предвидения - Европейскую систему для анализа стратегии и политики, или ЕСАСП, - которая «оценивает долгосрочные глобальные тенденции с тем, чтобы способствовать укреплению планирования политики. ... Что часто имеется в виду [в стратегическом плане], это уяснение цели, план действий, дорожная карта, компас, ощущение направления, ... преодоление топтания на месте и чисто реактивное поведение». ${ }^{75}$

Существует большая доля риска, что ЕС станет неадекватным в сфере безопасности - если он и был им когда-то. Страны-члены могут недооценивать уменьшение их роли, по крайней мере в международных делах. Конфликт в Ливии от 2011 года показал ограниченные возможности европейских стран и самого ЕС, и нынешних механизмов безопасности и обороны, так как Европа столкнулась с трудностями при проецировании силы (воздушные перевозки, топливо, логистика). Ливия должна была разбудить Европу, но затем пришли события в Мали, где Франция/ЕС были вынуждены просить о помощи в другой операции среднего масштаба поблизости от Европы.

При перечислении текущих проблем в документе ИИБЕС ${ }^{76}$ упоминается, что есть излишки ресурсов персонала и наземных сооружений; есть военные струк-

74 See Anna Barcikowska, Securing the Future of European Defense (Paris: EU Institute for Security Studies, July 2013).

75 Antonio Missiroli, "Strategic Foresight and the EU," Brief Issue 13 (Paris: EU Institute for Security Studies, 2013); доступно на http://www.iss.europa.eu/uploads/media/Brief_13.pdf.

76 Antonio Missiroli, ed., Enabling the Future European Military Capabilities 2013-2025: Challenges and Avenues, Report No. 16 (Paris: EU Institute for Security Studies, May 2013); доступно на http://www.iss.europa.eu/uploads/media/Report_16.pdf. 
туры, у которых имеются лишние боевые способности при нехватке других; рынок оборонного оборудования ЕС отличается высокой степенью фрагментации; ресурсы, предназначенные для исследований и разработок, остаются ограниченными и даже уменьшаются; междунациональная координация, кооперация и интеграция - от исследований до поставок, от логистики до планирования военных сил и обороны - остается недостаточной. К этому может быть добавлен факт, что политика ЕС распределена между разными отдельными агентствами и институтами, использующими средства, которые трудно собрать воедино для создания желаемой когерентности и синергии, и среди которых нет таких с исключительно военной компетентностью.

\section{Ребалансирование и Европа}

Учитывая проблемы, указанные выше, обречена ли Европа остаться только «нормативной силой»? В опубликованной ранее работе задавался вопрос, переживает ли Европа кризис безопасности на стратегическом уровне, и что случится, если Соединенные Штаты будут не в состоянии, или не будут иметь желания интервенировать в поддержку Европы. ${ }^{77}$ США уже очень выборочно начинают участвовать в войнах - они стремились к ограниченному вмешательству в Ливии, еще меньшему в Мали и почти никакому в Сирии. А что, если это и есть сущность ребалансирования?

Когда люди, принимающие решения в США, начали заниматься переносом стержня стратегии на Азию, европейцы занервничали. Во-первых, мы должны учесть, что «центр тяжести» (или «ребалансирование») имеет множество измерений: торговых, культурных и военных. С точки зрения Европы, чтобы ЕС имел право голоса в событиях, происходящих на его заднем дворе, способности, определяющие безопасность и оборону, не обязательно должны быть наступательными, как это принято в военной концепции США. Это стоило бы слишком дорого, не соответствовало бы европейскому способу мышления и было бы политически неприемлемо. Однако, должны быть созданы соответствующие модульные экспедиционные силы в соответствии с военными критериями (а не в соответствие с политической целесообразностью), предназначенные для действий как в случае гуманитарных (Ливия), так и в случае военных (Мали) кризисов. Но все это требует наличие вещи, которая является исключительным дефицитом в Европе - консенсуса, или политической воли, как вам угодно. Недостаточно упоминать значение трансатлантического сообщества и партнерства в речах. Как говорят игроки в покер, Европе надо делать ставки деньгами. Детям часто говорят, если ты ценишь что-то, то ты о нем заботишься. «Барак Обама не смотрит на мир традиционным «атлантическим» взглядом. Не так смотрят на мир и все больше американцев», предупреждает Майкл Кокс. «Старых определенностей, и частично, старой ди-

77 Cristian Iordan, "Defending Europe," Per Concordiam 3:2 (2012): 46-53; доступно на www.marshallcenter.org/mcpublicweb/MCDocs/files/College/F_Publications/perConcordium/ pcv3n2eng.pdf. 
пломатии, которые связывали западный альянс воедино, уже нет; чем скорее европейцы признают это, тем скорее они смогут найти новую роль для себя в этом быстро изменяющемся мире. Ответ находится в их - и в ничьих других - руках». ${ }^{78}$

Кроме того, увеличивающиеся оборонные расходы в Азиатско-Тихоокеанском регионе, разногласия по островам в Восточно-Китайском и Южно-Китайском морях (территориальные споры между Китаем и Филиппинами, Японией и другими) и распространение ядерных технологий должны в одинаковой степени интересовать всех стран-членов ЕС. Однако, подход ЕС в отличие от подхода США, направлен в основном на вопросы торговли и развития, как показало участие Кэтрин Эштон с самой большой делегацией официальных лиц ЕС в диалоге ЕСАСЕАН на министерском уровне в мае 2012 года. В официальном заявлении ЕС леди Эштон обещала углубление институциональных связей во всем, от контртерроризма до торговли, и выразилась даже еще более красноречиво: «США будут великой силой в Азии. Мы будем партнером Азии». ${ }^{79}$ И «есть сферы, в которых ЕС мог бы в потенциале играть полезную роль в безопасности Восточной Азии»: общие трансграничные проблемы, посредничество при конфликтах и потенциально, военную роль. ${ }^{80}$

\section{Причины для (умеренного) оптимизма?}

Но, может быть, не все потеряно. Чтобы быть справедливым, надо признать, что ЕС имеет преимущество в менеджменте гражданских и дипломатических кризисов (с дипломатическим персоналом численностью в 57000 по всему свету), что способствует его конкурентоспособности. После долгих лет кропотливой работы Европа успела осуществить успешное посредничество для заключения договоренностей между Сербией и Косово, используя свои дипломатические возможности. Как свидетельствует история создания ЕС, государствам необходимо некоторое время, чтобы понять и начать принимать участие в «политике малых шагов». Другой, имеющий отношение к теме, момент запланирован на декабрь 2013 года саммит ЕС, посвященный безопасности и обороне, - и подготовка пересмотра Европейской стратегии безопасности. Европейское стратегическое мышление воплощено в двух неформальных мозговых центрах, известных как «Европейская глобальная стратегия» и «Группа 'Будущее Европы'».

Первая инициатива «К Европейской глобальной стратегии: обеспечение влияния в изменяющемся мире», была реализована путем создания мозгового центра, объединившего представителей нескольких стран-членов (Италии, Польши, Испа-

78 Michael Cox, "No Longer Inevitable? The Transatlantic Relationship from Bush to Obama," in Europe in an Asian Century: Visions for Europe, LSE IDEAS, ed. Nicholas Kitchen (London: The London School of Economics and Political Science, 2012), 22-28.

79 Laurence Norman, "EU Looks to its Own Asia Pivot," Wall Street Journal (3 May 2012).

${ }^{80}$ Daniel Keohane, "The EU's Role in East Asian Security," in Look East, Act East: Transatlantic Agendas in the Asia Pacific, ed. Patryk Pawlak (Paris: EU Institute for Security Studies, December 2012), 45-50; доступно на http://www.iss.europa.eu/uploads/media/ Final_Report_13LEAE.pdf. 
нии и Швеции), и должна была вдохновить и дать толчок для формулирования будущей Европейской Глобальной Стратегии институциями ЕС и всеми странамичленами, причем центральную роль играл Верховный представитель Европейской службы иностранных действий. Стратегия основывается на понимании, что договоренность о стратегических целях ЕС повысит его готовность к действию, увеличит эффективность развертывания гражданских и военных способностей, например боевых групп. ${ }^{81}$ Необходимы изменения в том, как финансируются миссии $\mathrm{EC}$, с тем, чтобы улучшить развертывание и реализацию более справедливого распределения бремени между странами-членами, объединение и общее использование ресурсов группами из государств-членов, относящееся ко всем статьям оборонных расходов (исследования, поставки, эксплуатация и логистика, военное образование). ${ }^{82}$ В равной степени важным является интеграция оборонного рынка ЕС и координированные инвестиции в технологии двойного назначения.

Вторым интересным моментом является работа «Группы 'Будущее Европы'», которая объединяет министров иностранных дел Австрии, Бельгии, Дании, Франции, Италии, Германии, Люксембурга, Нидерландов, Польши, Португалии и Испании. Во внешнеполитическом плане группа идентифицировала несколько проблем и представила радикальные предложения:

- Усовершенствовать целостное функционирование ЕС, улучшая функционирование институций (Комиссии, Совета по иностранным делам)

- Ревизировать деятельность ЕСВД, Верховного представителя/ вице-президента, ответственных за ключевые области внешних действий

- Увеличить долю решений, принимаемых большинством в ОВПБ

- Совместное представительство в международных организациях

- Развитие Европейской политики по обороне с единым рынком для оружейных проектов и (по крайней мере для некоторых членов) с Европейской армией - амбициозный проект, выходящий за пределы простого объединения и общего использования ресурсов.

Обе инициативы, хотя они и неформальные, являются положительным развитием за последний год, намечают новый подход к стратегическим вызовам, перед которыми стоит Европа, предлагают конструктивную критику, чтобы решить эти проблемы. Они так же указывают на то, что Европе надо делать выбор и осуществлять изменения, некоторые из которых могут оказаться болезненными для экономики и суверенитета. Латать старое пальто уже недостаточно, пришло время менять его. Европейским государствам, возможно, понадобиться пересмотреть некоторые из своих главных амбиций, что для субъектов Союза будет очень

81 ЕС опубликовал комплект «Стандартов и критериев для боевых групп», которые основываются на существующих стандартов НАТО, с тем чтобы избежать дублирования и способствовать оперативной совместимости.

82 К примеру, Нидерланды отказались полностью от своего контингента танков, и объединили свою военноморскую подготовку с Бельгией. 
трудно принять - например, европейскую модель благосостояния, основанную на балансе населения с упором на сегмент молодых и активных граждан. Имея в виду, что статистика показывает, что население стареет, и не только в Европе, но и в «западных»/развитых странах, эту взлелеянную европейскую модель благосостояния уже нельзя будет поддерживать.

Другой элемент, с которым надо будет заниматься в будущем, связан с отношениями между ОПБО и НАТО, которые в настоящее время не являются полностью функциональными. По ряду причин, включающих в том числе ресурсные проблемы и фундаментальный здравый смысл, необходимо внести ясность и разделение труда, несмотря на отличие стран-членов, взглядов и стратегической культуры этих двух групп. Однако важно то, что некоторые из европейских государств, являющихся одновременно членами НАТО и ЕС, не считают, что в этих отношениях есть проблемы, скорее они друг другу помогают. Таковы случаи Польши и Румынии, которые в течение многих лет ясно декларировали свою приверженность как к трансатлантическому партнерству, так и к европейскому проекту, участвуя в сферах, связанных с безопасностью и в обеих организациях. Они очень активны в области безопасности и обороны и принимают активное участие в проекте противоракетной обороны НАТО, но так же принимают участие в инициативе создания европейских боевых групп (Польша, Франция, Германия) и представлены в неформальных европейских мозговых центрах.

И не на последнем месте, очень важным фактором является общественная поддержка в Европе - точнее со стороны молодых поколений, которые настроены категорически проевропейски, и они верят в роль, которую Европа может и должна играть в мире. Ценности, на которых основан ЕС и которые он продолжает поддерживать, как и ценности НАТО, универсальны: это демократия, уважение прав человека, индивидуальные свободы, уважение к меньшинствам; хорошее управление; мирное разрешение конфликтов; экономическая интеграция и свободная торговля. По всему миру известно, что ЕС поддерживает эти реалии и концепции. Действительно, сам по себе ЕС является лучшим примером успешной практической реализации перечисленных выше ценностей. Однако, Европа располагает небольшим набором средств для того, чтобы обеспечить соблюдение своих правил и ценностей, и каждый раз, когда она пыталась это сделать, получалось с оговорками: Западные Балканы, Африканский рог (антипиратские операции), Ливия, Мали и т.д. После двадцати лет усилий последние два примера являются показательными для состояния европейский амбиций, ${ }^{83}$ и они указывают на то, что европейцы не в состоянии сами справиться с кризисом по соседству, ситуация, которая усугубляется экономическим кризисом, необходимостью рационализировать расходы и ребалансированием стратегии США в сторону Тихого океана. Если когерентность и эффективность ОПБО увеличатся, ОПБО могла бы стать инстру-

83 Luis Simón, interview with Jolyon Howorth, European Geostrategy (4 September 2012); доступно на http://europeangeostrategy.ideasoneurope.eu/2012/09/04/interview-with-jolyonhoworth. 
ментом Европы для воплощения в жизнь того, во что Европа верит, когда ее дипломатические и переговорные умения для улаживания кризисов будут недостаточными или несоответствующими ситуации. Использование ОПБО не обязательно в качестве инструмента проецирования силы, à l'américaine, а как расширение международного права, которое Европа высоко ценит, «могло бы укрепить позиции ЕС как внутри его самого, так и за границей». ${ }^{84}$ Кроме того, силу нормативной Европы следует использовать и изучать по мере развития событий в Восточной Азии, так как Европа могла бы выборочно использовать свою международную ауру в деликатных дипломатических переговорах.

\section{Тенденции, риски, вызовы}

В последнее время несколько авторов рассмотрели отличия между американцами и европейцами по стратегическим и международным вопросам. В 2002 теория Роберта Кагана «Марса и Венеры» описывает, как гоббсовские США утверждают свою силу при преследовании своих целей, тогда как кантианские европейцы, не располагая такой силой, отдают предпочтение системе, основанной на правилах. Затем Роберт Купер в своем эссе о необходимости нового «либерального империализма» предупреждал европейцев не просмотреть важность военной силы в мире, который в ней еще нуждается. Купер идентифицировал постмодерный подход на европейском уровне, который отказывался от политики силы: но Европа не может снять свою защиту, взаимодействуя с миром, который этого не сделал.

Обстоятельства иракской войны от 2003 года напрягли трансатлантические отношения и подчеркнули отличия в подходах и в политике, которые особенно выпукло обозначились после прихода к власти президента Джорджа У. Буша. Избрание Барака Обамы, похоже, снова сблизило политические линии Соединенных Штатов и Европы. Но никто не увидел наиболее серьезной угрозы для западного альянса, а точнее кризис управления, который имел место по обе стороны Атлантического океана: в Соединенных Штатах - политическая дисфункция, тогда как ЕС боролся вернуть себе финансовую стабильность. ${ }^{85}$

\section{Теории раскола}

Разговоры об ослаблении Запада и упадка западного альянса начались снова на основании смены поколений и изменения глобального распределения сил - a именно, восхода множества не-западных государств/сил. Майкл Киммидж писал: «Для администрации Обамы Запад не есть субъект, который можно отвергать или обходить. Он просто не имеет значения. Обама и его поколение не были воспитаны верить в Запад. Упадок Запада был стимулирован Обамой его «сдвигом

${ }^{84}$ Mary Kaldor, "A European Conception of Security," in Europe in an Asian Century: Visions for Europe, LSE IDEAS, ed. Nicholas Kitchen (London: The London School of Economics and Political Science, 2012).

85 Charles A. Kupchan, “A Still-Strong Alliance,” Policy Review 172 (30 March 2012); доступно на http://www.hoover.org/publications/policy-review/article/111956. 
центра тяжести» в Азию. Европа оказалась впервые за несколько столетий глубокой провинцией. «Атлантический океан уступает свое место Тихому». ${ }^{86} \mathrm{~B}$ этих условиях, как отметил Саймон Серфати, сочетание строгости США и отделения Европы может вылиться в «некую форму неоизоляционизма, который ни Запад, ни остальные не могут себе позволить».

Но когда рассматриваем европейские и трансатлантические проблемы, надо упомянуть существенный факт: большинство членов НАТО являются и членами ЕС (22 из 28 для обеих организаций). Мы должны напомнить о существенных внутренних политических выборах (Норвегия два раза отказывалась от вхождения в ЕС и тем не менее активно участвует в НАТО); таких ограничениях, как нейтральность (Австрия); а иногда и простое соперничество (Турция и Греция). Европа весьма далека от того, чтобы быть блоком, хотя если рассматривать в целом, голые числа говорят красноречиво. Трансформирование ЕС - самой большой в мире экономики с самым большим в мире после Соединенных Штатов военным бюджетом - настоящей мягкой силы, в адекватного игрока и партнера на мировой арене, является огромным вызовом. Пока, хотя он и слабее, чем некоторые из его видных членов, ЕС далеко от неадекватности на международной арене благодаря своей внутренней, доказанной силе.

\section{Щели в броне НАТО?}

Что касается трансатлантического альянса, его сила проявляется в том факте, что он пережил угрозу, которая была смыслом его существования. Подумайте об известном изречении лорда Исмей о целях НАТО: США - в Европу, русские - вон из Европы, а Германия - под контролем! Шутки в сторону, основная дефиниция этого альянса все еще военно-политическая, он обеспечивает безопасность почти одного миллиарда людей, живущих в некоторых самых развитых капиталистических демократиях.

Но есть несколько пунктов, по которым НАТО сталкивается и будет сталкиваться с проблемами. Первый - это контекст его уменьшенных военных способностей. Недостатки европейцев всплыли на поверхность в ливийском эпизоде, предопределив появление таких категорических мнений, как мнение министра обороны США (тогда) Гейтса, который прямо заявил, что альянс ожидает «неясное, если не мрачное» будущее (2011). Как писали Хийтер Конли и Марен Лийд:

Попросту говоря, будущее НАТО зависит от перспектив на оборонные расходы в Европе и политическом желании Европы использовать способности, в которые она инвестирует эти расходы. Европейские военные способности фрагментированы, дублируются и стоят они больше, чем следовало бы. По сведениям НАТО, 26 европейских союзников вместе в 2011 году потратили 282 миллиарда долларов на воен-

${ }^{86}$ Michael Kimmage, "The Decline of the West: An American Story," Transatlantic Academy Paper Series (4 June 2013); доступно на www.transatlanticacademy.org/publications/declinewest-american-story.

87 Simon Serfaty, "The Folly of Forgetting the West," Policy Review 174 (1 August 2012). 
ные бюджеты (или около 27.2 процентов от всех расходов НАТО), тогда как Соединенные Штаты израсходовали 731 миллиардов (70.5 процентов). Политики Вашингтона сейчас хотят, чтобы НАТО быстро сдвинулось к отношению 50/50, а не оставалось бы альянсом с отношением расходов $75 / 25 .^{88}$

Если текущие тенденции демилитаризации и принятия нелогичных и неэффективных решений продолжатся и далее со сворачиванием европейских военных способностей до незначительных, «Европе грозит потеря геополитической адекватности». ${ }^{89}$ Европейцы в течение двух лет уже дважды показали, что не в состоянии действовать без военной помощи США. Однако, США обеспечили относительно ограниченное присутствие, «руководя с задней линии», отдавая должное факту, что (некоторые) европейские союзники имеют желание и могут действовать, когда в том есть необходимость. Но до каких пор? Сможет ли через несколько лет Франция выдержать другое Мали, имея в виду, что влияние уменьшения оборонных расходов еще не полностью чувствуется? Отсюда и ощущение американцев, что (малые) европейские страны являются потребителями безопасности, а не производителями, даже в контексте НАТО, что европейцы фокусируются на благосостоянии, а не на безопасности, а в случае необходимости, жертвы приходится нести Соединенным Штатам.

Кроме того, слышны голоса, спрашивающие, какое будущее ожидает НАТО после Афганистана, опасаясь, что не будет проекта, связанного с безопасностью, который связывал бы стран-членов в одно целое. Но таких проектов множество: новые вызовы безопасности, ограничения расходов на оборону в странах НАТО и «Умная оборона» являются важными для НАТО темами, над которыми военный и гражданский персонал могли бы думать без дыма и фейерверков. Проект все тот же, как и когда создавалось НАТО - улучшить нашу интеграцию и оперативную совместимость, планирование и боевую готовность для того, чтобы достойно встречать общие риски, угрозы и вызовы.

Генеральный секретарь НАТО Андерс Фог Расмуссен выразил свои опасения, что уход из Афганистана может стать извинением для будущих урезываний бюджетов. Наоборот, есть некоторые очень ценные уроки длившегося более десяти лет присутствия в Афганистане, которые - как заявил генеральный секретарь Расмуссен - необходимо сохранить и развить по мере перехода НАТО от боевых операций к тренировочной миссии в Афганистане, начиная с 2015 года. Инициатива названа «Инициатива 'Связанные силы'» (ИСС) и направлена на поддержание боеготовности и боевой эффективности НАТО через расширенное образование и квалификацию, увеличение числа и масштаба учений и лучшее использование технологий. 90

88 Heather A. Conley and Maren Leed, "NATO in the Land of Pretend," Center for Strategic and International Studies (26 June 2013); доступно на http://csis.org/print/44880.

89 Смотри Kupchan, "A Still-Strong Alliance."

90 The Connected Forces Initiative, NATO website, на www.nato.int/cps/en/SID-3A1489DD47A3C221/natolive/topics_98527.htm. 
Второе, инициатива «Умная оборона», определяемая Расмуссеном как «обновленная культура сотрудничества», ${ }^{1}$ поощряет союзников сотрудничать в разработке, приобретении и эксплуатации военных возможностей для того, чтобы встречать текущие проблемы безопасности в соответствии со стратегической концепцией НАТО. Этот подход включает объединение и общее использование ресурсов (так же рассмотренное в соответствующем разделе договора о ЕС), устанавливание приоритетов и лучшее координирование усилий. Другие союзники должны сузить трансатлантический разрыв, оборудовав себя способностями, которые считаются критическими, пригодными к развертыванию и устойчивыми. ${ }^{92}$ Но «Умная оборона» должна стать чем-то большим, чем слоган на наклейке на бампере, для того, чтобы обеспечить настоящее изменение в разработке и общем использовании критических способностей, необходимых для того, чтобы справляться с угрозами, ${ }^{33}$ для которых существенным элементом является политическая определенность. На этот момент успешным примером является Программа для стратегических перевозок по воздуху, объединяющая десять стран-членов и двух стран-партнеров, которая базируется в Венгрии и использует самолеты Boeing C17.

И последнее, есть два взаимосвязанных вопроса: успешное балансирование и артикулирование между ЕС и НАТО (в том числе и уточнение связей ОПБОНАТО, касающееся способностей, планирования, развертывания и т.д.) могло бы стать преимуществом при работе со странами, граничащими с ЕС (Северная Африка, Турция, Кавказ, Беларусь, Украина) и в привлечении к сотрудничеству России. Все эти вопросы будут оставаться в верхних рядах повестки дня НАТО, к которым следует добавить и несколько вопросов общего интереса: географическая близость, третирование новых вызовов безопасности, противоракетная оборона, энергетическая безопасность и т.д. В этой связи существенную роль играют Франция и Турция. Их гибкость и желание преодолеть прошлые отличия может изменить ситуацию.

\section{Возможности}

Попытка упрочить партнерство с экономической точки зрения была инициирована 14 июля 2013 года, когда Европейская комиссия от имени ЕС начала переговоры с Соединенными Штатами по партнерству в трансатлантической торговле и инвестициях (ТТИП), договоренности о зоне свободной торговли между Соединенными Штатами и Европейским Союзом. Хотя каждая из сторон, очевидно, пыта-

91 Прессконференция Генерального секретаря НАТО, Андерса Фог Расмуссена, после первой сессии Северо-Атлантического совета в формате глав стран и правительств. 20 мая 2012; доступно на www.nato.int/cps/en/natolive/opinions_87598.htm.

92 "Smart Defence," NATO website, доступно на www.nato.int/docu/review/Topics/EN/SmartDefence.htm.

93 Martynas Zapolskis, "NATO'S Strategic Challenges: The Alliance Strives to Maintain Integrity in an Uncertain Global Environment," Per Concordiam 4:2 (2013): 24-29. 
ется защитить определенные секторы своей экономики, эти договоренности являются самым большим существовавшим когда-либо двусторонним торговым соглашением, которое было предметом переговоров, и возможно, самым большим в мировой истории региональным соглашением о свободной торговле. Оно может привести к экономии миллионов евро для компаний и к созданию сотен тысяч рабочих мест, покрывая «более сорока процентов мирового ВНП, и большие доли мировой торговли и прямых иностранных инвестиций. ТТИП устранит все торговые тарифы и снизит нетарифные барьеры, в том числе и в сельском хозяйстве; расширит рыночный доступ к услугам; обеспечит лучшую нормативную гармонизацию; обеспечит защиту интеллектуальной собственности; ограничит субсидирование государственных предприятий и еще многое другое». ${ }^{94}$ Это приведет к большей взаимозависимости, к экономической и политической интеграции. Никто не может позволить себе разорвать эти связи, учитывая существенные экономические и социальные выгоды. ${ }^{95}$

Другая сфера, в которой трансатлантический диалог критически важен для обеспечения когерентного и эффективного подхода, - это защита критической инфраструктуры. Большая часть такой инфраструктуры в странах НАТО и ЕС находится во владении или под управлением частных компаний; еще большее значение имеет факт, что как военные, так и гражданские большую часть времени используют одни и те же волоконно-оптические кабели, энергетические сети и сети водоснабжения. На уровне ЕС процесс идентификации и регистрирования национальной и европейской критической инфраструктуры находится на достаточно продвинутой стадии, и страны-члены работают с публичным и частным сектором по установлению системы защитных мер. Теперь подумайте о защите информационных систем и сетей двадцати восьми стран-членов НАТО, от США до Албании. Я полагаю, это весьма непростой проект, связанный с безопасностью.

Чтобы НАТО оставалось основным средством трансатлантического сотрудничества, его роль должна углубляться и становиться более адекватной в таких областях, как новые вызовы безопасности, в том числе и кибербезопасность, ${ }^{96}$ превращая ее в сферу коллективной безопасности и обороны. Разработка общих стандартов показала свою полезность в сфере вооружений; она может оказаться полезной и в этой сфере. Кибертематика могла бы, наряду с другими темами, расширить связь между обоими берегами Атлантического океана, охватывая несколько подобластей - киберпреступность, кибершпионаж и кибервойну, - которые имеют большее или меньшее значение для атлантического сообщества (стран-членов и

94 Michael J. Boskin, “Transatlantic Trade Goes Global," Project Syndicate (16 July 2013); доступно на http://www.project-syndicate.org/commentary/the-global-implcations-of-eu-usfreet-trade-by-michael-boskin\#k0EPsyF5Mrk0ALsZ.99.

95 Смотри Thomas Ilgen, "The Future of the Transatlantic Partnership," in Hard Power, Soft Power and the Future of Transatlantic Relations, ed. Thomas Ilgen (Farnham, Surrey: Ashgate, 2006), 195.

96 "Cyberwar: War in the Fifth Domain," The Economist (1 July 2010); доступно на http://www.economist.com/node/16478792. 
международных организаций). Эта деятельность становится все более важной по мере того, как государства и международные организации сталкиваются с постоянно увеличивающимся числом попыток со стороны разных субъектов - спонсированных или нет государствами - получить незаконный доступ к чувствительной информации разного вида. Таким образом, сотрудничество в сфере кибербезопасности и киберобороны превращается в возможность для создания новых «альянсов» (на внутреннем и международном уровне), но так же и для развития предшествовавших усилий и опыта, углубляя существующие и функционирующие механизмы обеспечения безопасности.

Это может привести к реализации двух возможных сценариев:

1. Государства пойдут по пути неискренних высказываний, заявляя, что они желают работать вместе, тогда как на деле погрузятся в изоляционизм

2. Они преодолеют свои изоляционистские рефлексы и рефлекс выживания и построят настоящее сообщество субъектов, занимающихся проблемами безопасности.

Сотрудничество путем общего использования сведений об угрозах, в том числе и через публично-частное партнерство, ${ }^{97}$ может быть одним из способов превращения нашей культуры сотрудничества и открытость общества в конкурентное преимущество, позволяющее нам смягчать, останавливать и (что даже более важно) предотвращать нарушения информационной безопасности и компьютерные атаки.

Трансатлантические отношения двадцать первого века не обязательно означают расположенные в Европе танки и штурмовики A10 Thunderbolts CША, а то, что государства по обеим сторонам Атлантического океана организуют переход к миру, в котором Запад больше не берет на себя ответственность за все происходящее в мире, продолжая, однако, работать с другими для решения новых и сложных проблем. Мы можем найти силу в нашей многочисленности и в способе, с помощью которым мы функционируем; трансатлантическая солидарность все еще основана на наших общих интересах и ценностях. Джеймс Хаускофт писал: «Сегодня военные партнерства более важны, чем когда-либо раньше. Нынешняя национальная стратегия Америки, в сочетании с глобальными финансовыми и политическими проблемами, предполагают, что маловероятно, чтобы американцы в одностороннем порядке применяли вооруженную силу для разрешения проблем безопасности 21 века». ${ }^{98}$ Сейчас подходящий момент для расширения сотрудничества в таких тонких областях, как разведка и кибербезопасность (если это уже не случилось). Учитывая это, надо иметь в виду, что есть нечто, что трансатлантические лидеры должны рассмотреть: как наилучшим образом привлечь насе-

97 Смотри Wade Williamson, "Combating Emerging Threats Through Security Collaboration," Security Week (17 December 2012); доступно на www.securityweek.com/combatingemerging-threats-through-security-collaboration.

98 James Howcroft, "Things Americans Need to Know: How to Be Better Partners," Small Wars Journal (25 June 2013); доступно на http://smallwarsjournal.com/print/14148. 
ление к участию в решении сегодняшних и будущих вызовов и угроз безопасности.

Обеим сторонам кое-чему надо научиться, и они должны поддерживать друг друга, так как условия геополитики двадцать первого века не позволяют им действовать на мировой сцене поодиночке. Европейский подход мягкой силы к международным делам может дать полезное понимание некоторых проблем и оказать поддержку интересам США. «Для многих ключевых проблем сегодняшнего дня международной финансовой стабильности, незаконной торговли наркотиками, распространения болезней и в особенности терроризма - военная сила просто не может привести к успеху, а ее использование иногда может оказаться контрпродуктивным. Вместо этого, США должны сотрудничать с Европой и с другими игроками, чтобы справиться с этими общими угрозами и проблемами».99 В самом деле, в недавней статье ген. Дэвид Петреус отдал должное значению (такой иностранной помощи) как мягкая сила, наряду с вооруженными силами, для улучшения состояния национальной безопасности и продвижения глобальных интересов США. ${ }^{100} Э$ то измерение (мягкая сила) ЕС доказало свою ценность, внеся существенный вклад в достижение мира и обеспечение стабильности на Балканах, и у него есть потенциал стать способом нахождения устойчивых, долгосрочных решений. Перспектива присоединения Турции к ЕС, а так же специальные торговые соглашения с Северной Африкой могут стать полезными инструментами для обеспечения стабильности по соседству с Европой. Таким образом возникает вопрос - есть ли возможность экспортировать европейскую модель по всему миру: могут ли мир, стабильность и развитие найти благодатную почву в других местах, при других условиях? Как сформулировал это Джоузеф Най, «чтобы сотрудничество в сфере безопасности работало, для США, возможно, будет необходимо заново открыть ценность «мягкой силы», а европейцам - создать свои собственные ресурсы «жесткой» силы». 101

Хотя трудно найти правильный баланс, я бы высказал предположение, что трансатлантический альянс все еще «неизбежен». ${ }^{102}$ Но есть сильная необходимость в политической воле, со стороны парламентов и правительств по обе стороны Атлантического океана, не на последнем месте по вопросам бюджетного дефицита, и еще в большей степени, в объяснении избирателям, почему важно инвестировать деньги в безопасность и оборону, обрисовав цену провалов в сфере безопасности. В Европе, по крайней мере, этот вопрос не стал значимым предме-

99 Joseph Nye, "Soft Power and European-American Affairs," in Hard Power, Soft Power and the Future of Transatlantic Relations, ed. Thomas Ilgen (Farnham, Surrey: Ashgate, 2006), 25-35.

${ }^{100}$ Gen. David Petraeus and Michael O'Hanlon, "Fund-Don't Cut-U.S. Soft Power," Politico (30 April 2013); доступно на http://www.politico.com/story/2013/04/david-petraeus-defensediplomacy-soft-power-90781.html\#ixzz2a8Y1fbSt.

101 Nye, "Soft Power and European-American Affairs."

102 Vittorio Parsi, The Inevitable Alliance: Europe and the United States Beyond Iraq (London: Palgrave Macmillan, 2006). 
том общественных дискуссий. Чтобы мы оставались жизнеспособными партнерами, участвующими в эффективном сотрудничестве, состояние дел должно измениться.

\section{Выводы}

Слово «неустойчивость» описывает состояние международной системы сегодня, точнее, чем когда-либо. Мы стали свидетелями восхода нескольких других государств, но на всех них - в разной степени - оказал влияние экономический и финансовый кризис, или внутренние проблемы и небалансы, которые загнали в тупик их восход к статусу «великих сил». Поэтому теории мультиполярности или многоцентричности (в зависимости от точки зрения) все еще являются спорными.

Роль и могущество Соединенных Штатов ослабли и подверглись сомнению благодаря их внутренним экономическим проблемам, что привело к урезанию бюджетов на оборону и уменьшению военных способностей. И все-таки, несмотря на текущие проблемы, возможности вернуть утраченные позиции все еще под рукой: «жизнеспособные альянсы и партнерства, экономическая адаптивность, гибкость и инновации, значительная привлекательность мягкой силы в культуре и идеологии открытых обществ», ${ }^{103}$ перспективы на энергетическую независимость и проистекающий из нее экономический рост, лучшие университеты в мире и общее ощущение целенаправленности. Кроме того, проецирование ВНП не может быть единственным аргументом для потенциального подъема других государств до статуса великих сил. Ключ, утверждает Най, находится в сочетании жесткой силы принуждения и вознаграждения с мягкой силой убеждения и привлечения к успешным стратегиям - сочетание, которое можно классифицировать как умную силу.

В течение столетий Европа была домом самых больших в мире великих сил, как и полем боя для них. Мы преодолели этот печальный и кровавый эпизод нашей истории, добившись самого долгого периода мира и стабильности в европейской истории, став глобальной моделью и защитником демократии, прав человека, верховенства закона, социального благополучия, здравоохранения и мирного разрешения конфликтов. Мир приносил свои дивиденды. Но этот расцвет в немалой степени обязан трансатлантическим отношениям и безопасности, которую они обеспечивали.

Однако теперь Европе следует уделять больше внимания «другим» средствам, которые могут быть использованы для разрешения проблем в наших иногда взрывоопасных окрестностях. Мы продолжаем наблюдать, как военная сила Европы уменьшается - в течении двух лет мы стали свидетелями таких обескураживающих случаев как Ливия и Мали. Почему важно заниматься этими проблемами? При отсутствии достаточных военных способностей Европа может оказаться в тупике, в уязвимой позиции, может оказаться не в состоянии справляться с воен-

${ }^{103}$ Joseph Nye, The Future of Power (New York: Public Affairs, 2011). 
ными кризисами в своих окрестностях, по крайней мере в среднесрочной перспективе.

Это не означает, что Европа или США или кто-то другой должен занимать воинственную позицию. Вовсе нет. Я не предлагаю обязательное следование доктрине либерального империализма, но здравый смысл говорит нам, что армии не предназначены для уборки снега и расчистки дорог зимой. Вооруженные силы не предназначены для обеспечения социального благополучия военнослужащих, они должны быть жесткой, мобильной, оперативно совместимой, с хорошими коммуникациями силой, которая реагирует и действует быстро, если есть причины (гуманитарные или другие), на основании которых ООН дает такие санкции, противодействовать угрозам двадцать первого века, которые имеют потенциал вызвать большие сбои в нашем обществе.

Является ли все еще работоспособным трансатлантический механизм? НАТО готовится уйти из Афганистана, и нет гарантий, что вследствие этого все получат дивиденды мира. Трансатлантический альянс тоже стоит перед лицом логики «делать больше с меньшим», тема уменьшения бюджетов на безопасность и оборону неизбежна. Внимание к новым вызовам безопасности увеличится. Кибербезопасность будет среди факторов, которые приведут к изменению стратегии национальной безопасности и обороны, стратегического мировоззрения НАТО и атлантического партнерства, как возможной (среди прочих) сферы углубления сотрудничества между западными демократиями.

Что касается пути вперед, обеим сторонам надо внести коррекции, углубляя политический кураж и перспективность. Европа должна знать свои сильные стороны, найти и обновить свою приверженность к дальнейшему развитию европейского проекта, стать более ответственной и надежной в своей внешней политике и региональной безопасности и обороне. Европа должна справиться со своими демографическими проблемами, с уменьшением и старением населения, ${ }^{104}$ которое будет оказывать увеличивающееся влияние на систему социального обеспечения. По инициативе Европейской комиссии стартовал интересный процесс, направленный на укрепление европейской оборонной промышленности путем создания единого европейского оборонного рынка. Чтобы стать настоящим партнером, европейцам надо снова иметь в виду старую, знакомую концепцию «разделения бремени», но на этот раз по-настоящему. Это предполагает изменение мышления Европы, увеличение внимания к безопасности и обороне, чтобы найти подходящие источники финансирования, принятие реалистических военных бюджетов и создание более адекватных подходов к оборонному сотрудничеству.

Оборонный истэблишмент США должен внимательно и ответственно заняться национальным бюджетным дефицитом и его последствиями как на внутренние измерения (к примеру на инвестиции в инфраструктуру), так и на инструменты проецирования силы (жесткая сила, военные и разведывательные способности, но

${ }^{104}$ Смотри Matthew Rhodes, "U.S. perspectives on NATO," in Understanding NATO in the $21^{\text {st }}$ Century, ed. Graeme P. Herd and John Kreindler (New York: Routledge, 2013), 33-49. 
также и мягкая сила, союзы, иностранная помощь, дипломатия и культура). «Соединенным Штатам необходимо смотреть на Европу как на часть глобальной стратегии, а не как на реликвию прошлого, которую можно выкинуть, когда Америка начнет осуществлять свою азиатскую стратегию. ... Соединенные Штаты и Европа сейчас должны прокладывать путь в определении международного порядка будущего - порядка, который дает простор для развития новым регионам и силам, обеспечивая их поддержку в укреплении основных демократических ценностей и либерального международного экономического порядка, который привел нас туда, где мы находимся. Это можно осуществить, но - как и в 2002 году - это означает, что мы должны преодолеть нашу склонность играть роли Марса и Венеры и вложить все наши усилия в достижение общей цели. ${ }^{105}$

В целом, мы живем во времена перемен, неустойчивости и стратегических сдвигов. Но выборы, которые мы делаем сейчас, определят наше будущее. Так называемый «упадок Запада» может случиться еще не скоро. А что, если самым большим вызовом для европейцев и американцев является продолжение того, что мы начали вместе, продолжение и углубление нашего партнерства? Для этого есть множество причин: мы не должны недооценивать силу наших общих ценностей, доверия, общей цивилизации и, да, наших общих целей. Вместе мы являемся самой большой в мире экономической, военной и - не на последнем месте - мягкой силой в мире.

Не существует жизнеспособной альтернативы трансатлантическому сотрудничеству. За истекшие годы оно показало свои преимущества, и определенно, будет их демонстрировать и в будущем, в рамках НАТО, на политическом и военном уровне, или (будем надеяться скоро) в рамках ТТИП ${ }^{106}$ на экономическом и торговом уровне. Кроме того, в мультиполярном, полицентрическом, мультимодальном и даже мультиплексном мире как США, так и Европа, будут терять часть своего влияния на международные дела, и в результате окажутся в таком положении, чтобы во все большей степени полагаться друг на друга, взаимно усиливая друг друга, основываясь на своей общей истории, ценностях и - будем надеяться - точек зрения, интересов, доверия, разрешая проблемы, с которыми нельзя справиться по отдельности, как например, климатические изменения, изменения в глобальном управлении, кибер(не)безопасность, и т.д. Хотя время от времени они могут иметь свои сложности, наши отношения должны продолжаться.

${ }^{105}$ Kurt Volker, "Reaffirming Transatlantic Unity," Policy Review 172 (30 March 2012); доступно на http://www.hoover.org/publications/policy-review/article/112246.

106 Трансатлантическое Торговое и Инвестиционное Партнерство (ТТИП) представляет собой развитие более глубоких и интегральных отношений между двумя самыми большими в мире экономиками - США и ЕС - и предлагает существенные потенциальные выгоды как потребителям, так и компаниям. Смотри www.acus.org/content/ttip. 


\section{Литература}

"Looking Forward: U.S. National Security Beyond the Wars." In Conference organized by the Center for a New American Security, 56-63. Vol. 189 ., 2013.

Acemoglu, Daron, and James Robinson. Why Nations Fail. The Origins of Power, Prosperity and Poverty. London: Profile Books, 2012.

Alexander, David. Defense Chief Orders Strategy Review in Response to Budget Cuts. Reuters, 2013.

Alexander, David. Update 1 - Pentagon Delays Carrier's Mideast Deployment over Budget Woes. Reuters, 2013.

Alter, Benjamin, and Edward Fishman. "The Dark Side Of Energy Independence." The New York Times (2013).

Andersson, Jan Joel. The Transatlantic Relationship. Swedish Institute of International Affairs (UI), 2013.

Bacevich, Andrew. "Let Europe Be Europe: Why the United States Must Withdraw from NATO." Foreign Policy (2010).

Barcikowska, Anna. Securing the Future of European Defense. Paris: EU Institute for Security Studies, 2013.

Boskin, Michael J.. Transatlantic Trade Goes Global. Project Syndicate, 2013.

Brzezinski, Zbigniew. "After America." Foreign Policy (2012): 26-29.

Caporaso, James A.. "The European Union and Forms of State: Westphalian, Regulatory or Post-modern?" Journal of Common Market Studies 34, no. 1 (1996): 29-52.

China and Iran: Best Chance for a 'Multipolar' World. Stratfor, 2004.

Clinton, Hillary. "America’s Pacific Century." Foreign Policy (2011).

Conley, Heather A., and Maren Leed. NATO in the Land of Pretend. Center for Strategic and International Studies, 2013.

Cox, Michael. "No Longer Inevitable? The Transatlantic Relationship from Bush to Obama." In Europe in an Asian Century: Visions for Europe, LSE IDEAS, 22-28. London: The London School of Economics and Political Science, 2012.

Ferguson, Niall. "A World Without Power." Foreign Policy 143 (2004): 32-39.

Freedberg, Jr., Sydney J., and Colin Clark. Navy, Northrop Score Historic First With (Mostly) Successful X-47B Drone Carrier Landings. Breaking Defense, 2013.

G. Ikenberry, John. "The Rise of China and the Future of the West." Foreign Affairs 87, no. 1 (2008). 
Ginsberg, Roy H.. "Conceptualizing the European Union as an International Actor: Narrowing the Theoretical Capability-Expectations Gap." Journal of Common Market Studies 37, no. 3 (1999): 429-454.

Global Trends 2030: Alternative Worlds. U.S. National Intelligence Council, 2012.

Gnesotto, Nicole. La politique de sécurité et de défense de l'UE. Les cinq premières années (1999 - 2004). Paris: EU Institute for Security Studies, 2004.

Gordon, IV, John, and John Matsumura. The Army's Role in Overcoming Anti-Access and Area Denial Challenges. Santa Monica, CA: RAND Corporation, 2013.

Gross, Eva. The American Sequester and Us. European Union Institute for Security Studies, 2013.

Haass, Richard N.. "The Second American Century? It's Already Here." Washington Post (2013).

Hendrix, Henry J.. At What Cost a Carrier?. Center for a New American Security, 2013.

Hobsbawm, Eric. "War, Peace and Hegemony at the Beginning of the Twenty-First Century." In War, Peace and Hegemony in a Globalized World, 15-24. New York: Routledge, 2008.

Hooker, Richard D.. "'The Strange Voyage': A Short Précis on Strategy." Parameters 42 (2013): 59-68.

Howcroft, James. Things Americans Need to Know: How to Be Better Partners. Small Wars Journal, 2013.

Ilgen, Thomas. "The Future of the Transatlantic Partnership." In Hard Power, Soft Power and the Future of Transatlantic Relations, 195. Farnham, Surrey: Ashgate, 2006.

Iordan, Cristian. "Defending Europe." Per Concordiam 3, no. 2 (2012): 46-53.

Iordan, Cristian. "Le système européen d'acquisition d'armements. Facteur de soutien de la PESD." Romanian Journal of European Affairs 10, no. 4 (2010): 87.

J. Cole, Michael. "The DF-21D or 'Carrier Killer': An Instrument of Deception?" The Diplomat (2013).

Joyner, James. Jones: 'Pivot to Asia' Regrettable Word Choice. New Atlanticist, 2013.

Jupille, Joseph, and James A. Caporaso. "States, Agency and Rules: The European Union in Global Environment Politics." In The European Union in the World Community, 213-229. Boulder, CO: Lynne Rienner, 1998.

Kagan, Robert. Of Paradise and Power: America and Europe in the New World Order. New York: Alfred Knopf, 2003. 
Kahler, Miles. "Rising Powers and Global Governance: Negotiating Change in a Resilient Status Quo." International Affairs 89, no. 3 (2013): 711-29.

Kaldor, Mary. "A European Conception of Security." In Europe in an Asian Century: Visions for Europe, LSE IDEAS. London: The London School of Economics and Political Science, 2012.

Kaplan, Robert D.. Anarchy and Hegemony. Stratfor, 2013.

Kaplan, Robert D.. The Virtues of Hard Power. Stratfor, 2013.

Keohane, Daniel. The EU's Role in East Asian Security In Look East, Act East: Transatlantic Agendas in the Asia Pacific. Paris: EU Institute for Security Studies, 2012.

Keynote speech by NATO Secretary General Anders Fogh Rasmussen at the NATO Parliamentary Assembly in Prague., 2012.

Kimmage, Michael. The Decline of the West: An American Story In Transatlantic Academy Paper Series., 2013.

Kitchen, Nicholas. The United States After Unipolarity: Executive Summary In IDEAS reports. London: London School of Economics and Political Science, 2011.

Korb, Lawrence J., Alex Rothman, and Max Hoffman. Reforming Military Compensation: Addressing Runaway Personnel Costs Is a National Imperative. Center for American Progress, 2012.

Kupchan, Charles A.. "A Still-Strong Alliance." Policy Review 172 (2012).

Layne, Christopher. "From Preponderance to Offshore Balancing: America's Future Grand Strategy." International Security 22, no. 1 (1997): 86-124.

Layne, Christopher. "Offshore Balancing Revisited." The Washington Quarterly 25, no. 2 (2002): 233-248, quote on 245.

Manners, Ian. "Normative Power Europe: A Contradiction in Terms?" JCMS 40, no. 2 (2002): 252-53.

Maull, H.W.. "Germany and Japan: The New Civilian Powers." Foreign Affairs 69, no. 5 (1990): 92-93.

Mazarr, Michael J.. Discriminate Power: A Strategy for a Sustainable National Security Posture In The Philadelphia Papers. NDU Strategy Study Group, 2013.

Mearsheimer, John J.. The Tragedy of Great Power Politics. New York: Norton, 2001.

Missiroli, Antonio. Enabling the Future European Military Capabilities 2013-2025:

Challenges and Avenues. Paris: EU Institute for Security Studies, 2013. 
Missiroli, Antonio. Strategic Foresight and the EU. Paris: EU Institute for Security Studies, 2013.

Nye, Joseph S.. "The Future of American Power." In War, Peace and Hegemony in a Globalized World, 36-49. New York: Routledge, 2008.

Nye, Joseph S.. Soft Power: The Means to Success in World Politics. New York: PublicAffairs, 2004.

Nye, Joseph S.. The Future of Power. New York: PublicAffairs, 2011.

Nye, Joseph. "Soft Power and European-American Affairs." In Hard Power, Soft Power and the Future of Transatlantic Relations, 25-35. Farnham, Surrey: Ashgate, 2006.

Overview - United States Department of Defense Fiscal Year 2013 Budget Request. Washington, D.C.: U.S. Department of Defense, 2012.

Parsi, Vittorio. The Inevitable Alliance: Europe and the United States Beyond Iraq. London: Palgrave Macmillan, 2006.

Petiteville, Franck. "L’Union Européenne comme acteur international 'global.' Un agenda de recherche." Revue Internationale et Stratégique 47, no. 3 (2002): 145-57.

Petiteville, Franck. La politique internationale de l'Union Européenne. Paris: Presses Sciences Po, 2006.

Posen, Barry R.. "Pull Back: The Case for a Less Activist Foreign Policy." Foreign Affairs 92, no. 1 (2013).

Rhodes, Matthew. "U.S. perspectives on NATO." In Understanding NATO in the 21st Century, 33-49. New York: Routledge, 2013.

Roulo, Claudette. Hagel Meets with Troops on Fort Bragg, Discussed Budget. U.S. Department of Defense Website, 2013.

Rytz, Henriette. The Pivot to Asia - Overcoming a Communication Problem. German Institute for International and Security Affairs (SWP), 2013.

Serfaty, Simon. "The Folly of Forgetting the West." Policy Review 174 (2012).

Sharma, Ruchir. "Broken BRICs: Why the Rest Stopped Rising." Foreign Affairs (2012): 2-7.

SIPRI Yearbook 2013: Armaments, Disarmament and International Security. Stockholm: SIPRI, 2013.

Smith, Karen. "The End of Civilian Power EU: A Welcome Demise or Cause for Concern?" The International Spectator 35, no. 2 (2000): 11-28.

Tata, Samir. "Recalibrating American Grand Strategy: Softening U.S. Policies Toward Iran in order to Contain China." Parameters 42/43 (2013): 47-58. 
Vezirgiannidou, Sevasti-Eleni. "The United States and Rising Powers in a Posthegemonic Global Order." International Affairs 89, no. 3 (2013): 635-51.

Volker, Kurt. "Reaffirming Transatlantic Unity." Policy Review 172 (2012).

Williamson, Wade. Combating Emerging Threats Through Security Collaboration. Security Week, 2012.

Zakheim, Dov S.. "The Strategic Implications of a Freefalling U.S. Defense Budget." The American Interest (2013): 43-51.

Zapolskis, Martynas. "NATO'S Strategic Challenges: The Alliance Strives to Maintain Integrity in an Uncertain Global Environment." Per Concordiam 4, no. 2 (2013): 24-29. 